\title{
The Growth and Distributive Impacts of Public Infrastructure Investments in the Philippines
}

\author{
Erwin Corong, Lawrence Dacuycuy, Rachel Reyes, and Angelo Taningco
}

\section{Introduction}

The government of the Philippines continues to implement reforms that aim to promote economic development and lift the country's standard of living. This is critical as it has been lagging behind neighbouring East Asian countries with respect to economic size and per capita income. ${ }^{1}$ The bottlenecks the country faces include poor physical infrastructure (transport and utility infrastructures), low quality of education, volatile economic growth, high poverty rates and large income disparities.

Various business surveys have pointed to the relatively poor quality of transportation infrastructure in the country, such as airports, maritime ports, roads and railroads. Energy and water infrastructures have also not been fully developed, and concerns over a possible crisis in power and water have recently mounted. Public

\footnotetext{
${ }^{1}$ Based on the World Bank's World Development Indicators database 2009 Philippine GDP, at constant 2000 prices and adjusted for purchasing power parity (PPP), stood at US\$295.8 billion. This is lower than in most other East Asian countries, including the People's Republic of China or PRC (US\$8.2 trillion), Indonesia (US\$877 billion), Japan (US\$3.8 trillion), Republic of Korea (US $\$ 1.2$ trillion), Malaysia (US\$348.2 billion) and Thailand (US $\$ 491.8$ billion). This contrasts with the situation, in 1980, when Philippine PPP-adjusted real GDP was US\$126 billion, much higher than Malaysia (US\$67.3 billion) and Thailand (US\$105.4 billion). Moreover, the PPP-adjusted GDP per capita at 2005 prices for the Philippines was US\$3,216, lower than in the PRC (US $\$ 6,200$ ), Indonesia (US\$3,813), Japan (US\$29,688), Korea (US\$25,493), Malaysia (US\$12,678), Singapore (US\$45,978) and Thailand (US\$7,258).

E. Corong $(\bowtie)$

Center of Policy Studies, Monash University, Melbourne, Australia

e-mail: erwin.corong@monash.edu
}

L. Dacuycuy $\bullet$ R. Reyes $\bullet$ A. Taningco

School of Economics, De La Salle University, Manila, Philippines

e-mail: lawrence.dacuycuy@dlsu.edu.ph; reyesrc@dlsu.edu.ph; angelo.taningco@dlsu.edu.ph 
spending on education has also been criticized as being low compared to neighbouring countries in the region, resulting in a weak public education system.

Against this backdrop, the government of the Philippines has engaged in policy measures to improve the quality of public infrastructure (especially in relation to transport and utilities) and public education in order to ensure and sustain robust growth and to alleviate poverty. To speed up public infrastructure development in the presence of fiscal constraints, the government has revived the promotion of partnerships with the private sector (in Build-operate-transfer schemes), with the private sector providing financial and technical expertise for selected infrastructure projects.

This paper contributes to policy analysis in the Philippines by providing a quantitative assessment of the growth and distributive impacts of increasing spending on public infrastructure, such as in transportation, utilities and education. Since these issues are interlinked, a computable general equilibrium (CGE) model is employed together with a micro-simulation model in order to trace the channels whereby public infrastructure investments filter through the Philippine economy. We use Philippine data in a dynamic CGE model developed by Dissou and Didic (2011) which explicitly models public capital as an input in firms' production process. The results of the CGE simulations are then used as inputs into a microsimulation module following Cockburn, Duclos and Tiberti (2011) in order to assess the distributive impacts of an increase in public infrastructure investments.

To provide input to policy makers, we conduct two experiments to assess the potential immediate, short-run and long-run effects of increased public investment expenditures, when financed by either higher taxes or foreign borrowing. The policy focus of this paper leads us to stay within the confines of attainable government policies by simulating a $25 \%$ permanent increase in the public infrastructure expenditures-to-GDP (PIE-GDP) ratio over time. This increase is sufficient to achieve the government's minimum target of a $5 \%$ PIE-to-GDP ratio.

The next sections are as follows. Section "Public Infrastructure" provides a brief survey of the public investment literature and the section "Public Infrastucture Challenges" discusses issues relating to public infrastructure in the Philippines. Section "Philippine Poverty Profile" presents a poverty profile of the Philippines. Section "Methodology" describes the CGE model and the micro-simulation module, then sections "Policy Experiments" and "Simulation Results" respectively explain the simulation scenarios and the simulation results. Finally, the section "Summary and Insights" provides insights and conclusions.

\section{Public Infrastructure}

Empirical research on the economic impact of public infrastructure is now widespread. One strand in the literature makes use of econometric modeling techniques. In a seminal paper, Aschauer (1989) uses an OLS approach to show that the capital stock of public infrastructure is a determinant of total factor productivity in the 
United States. Isaksson (2009) adopts a panel data regression model-using ordinary least squares (OLS), both fixed and random effects, and instrumental variables - to analyze a group of 57 advanced and developing countries over 1970-2000. His research finds that public capital has a relatively strong impact on industrial development and that public capital growth has the strongest impact on rapidly growing economies and high-income economies.

Calderon and Chong (2004) use a generalized method of moments (GMM) dynamic panel estimation model to capture the role of the volume and quantity of infrastructure-particularly in energy, public works, railways, roads and telecommunications - on income distributions in a set of 101 countries over 1960-1995. Their study reveals a negative relationship between the level of infrastructural development and income inequality. Arslanalp, Bornhorst and Gupta (2011) use a production function with estimated public capital in 48 advanced and developing economies over 1960-2001. They find that increases in the stock of public capital are associated with economic growth, with advanced economies registering stronger short-run effects and developing economies having greater long-run effects. Gupta et al. (2011) adopt a production function approach with a GMM estimation. They use efficiency-adjusted public capital stock data for 52 developing countries, and find that this type of public capital has a significant effect on output.

Other related studies have opted for general equilibrium techniques. Zhai (2010) uses a global CGE model, and finds that regional infrastructure investment in developing Asia would raise global income by US $\$ 1.8$ trillion by the year 2020, with $90 \%$ of the gains accruing to the region. Moreover, such investment would help boost global and regional trade. Dissou and Didic (2011) use a CGE model with heterogeneous agents and public capital in a multi-sectoral and intertemporal environment calibrated to the economy of Benin. They show, among other things, that: increasing public investment has short-run Dutch disease effects, expected to be offset by increased productive capacity in the long run; higher public infrastructure spending benefits non-constrained agents more than constrained agents; and that the short-run private sector investment response depends on how the public infrastructure is financed.

Unfortunately, empirical research on the role of infrastructure spending on economic growth and poverty in the Philippines - a developing economy in Southeast Asia-is limited. Teruel and Kuroda (2005) use a translog cost function and find that improvements in public infrastructure in the Philippines-particularly road infrastructure-are instrumental in enhancing agricultural productivity in the country. Savard (2010), using a top-down bottom-up computable general equilibrium (CGE) micro-simulation model, demonstrates the macro, sectoral and poverty impacts of increasing public investment in the Philippines. The findings indicate that: public investment positively impacts GDP and employment; the macro effects do not differ substantially across the three public investment financing mechanisms considered (income tax, value-added tax (VAT) and foreign aid); public investment lowers poverty - the magnitude being strongest under VAT; and foreign aid is the most equitable funding mechanism. 
A contentious empirical issue is the estimation of the elasticity of output to public capital, which has been criticized in several studies as being too high, as a result of some methodological limitations or weaknesses. Isaksson (2009) points out that this concern arose because Aschauer's (1989) estimate of the effect of public investment is impossibly large, ranging from 0.38 to 0.56 , implying an annual rate of return of no less than $100 \%$. Potential sources of this problem vary and those cited in the literature include endogeneity, reverse causality (from output growth to public capital), spurious correlation (due to non-stationarity of the data), omitted state-dependent variables and lack of agreement regarding the appropriate rate of return from public investment.

Furthermore, it has been conjectured that the large estimates on the elasticity of output to public capital could emanate from: high public investment (as a proportion of GDP), a situation which is prevalent in highly corrupt countries, as corruption tends to inflate public investments; from unproductive uses in public capital; and from the composition of public capital. Several papers have attempted to correct for these econometric and conceptual problems by accounting for the elasticity of output to public capital, including Arslanalp, Bornhorst and Gupta (2011), Gupta et al. (2011) and Isaksson (2009).

\section{Public Infrastucture Challenges}

It has been widely perceived that Philippine transport infrastructure-air transport, ports, railroads, roads - is of poor quality and has not improved much in recent years. The latest World Economic Forum's (WEF 2010) Executive Opinion Survey, published in its Global Competitiveness Report (GCR) 2010-2011, ranked the Philippines 113th out of 139 countries in the overall quality of its infrastructure, giving the country a score of 3.2 (the possible score ranges from 1 [worst] to 7 [best]). More specifically, the Philippines ranked 97th in railroad infrastructure, 112th in air transport infrastructure, 114th in road infrastructure and 131st in port infrastructure. This suggests that, by international standards, the overall quality of Philippine infrastructure is relatively poor. Indeed, Fig. 1 confirms that, between 2004 and 2010, infrastructure indicator scores deteriorated slightly in relation to air transport, ports and railroads, while the score on road infrastructure remained unchanged.

\section{Infrastructure Trends}

The road network in the Philippines expanded during the 1990s, then began to deteriorate, falling to $200,037 \mathrm{~km}$ in 2003 (the most recent data available) from $202,123 \mathrm{~km}$ a year earlier. The proportion of paved roads in the national road 


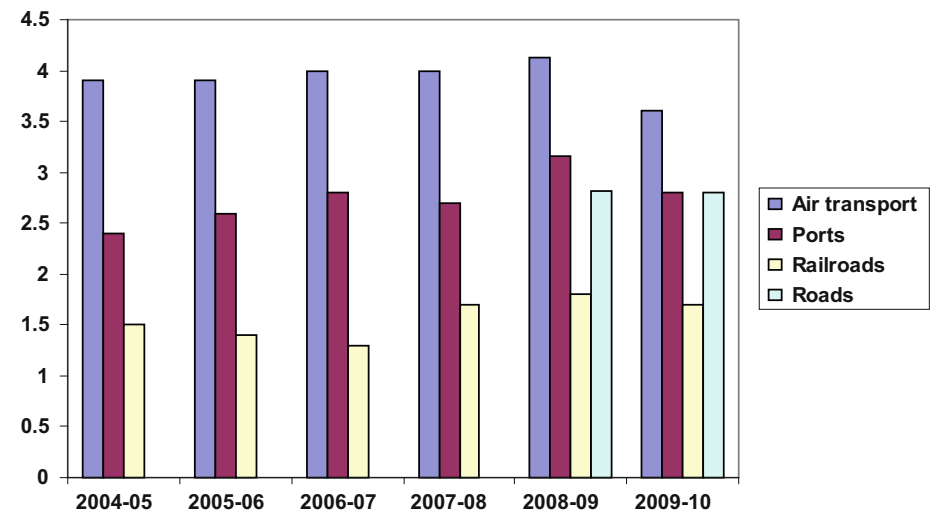

Fig. 1 World Economic Forum's Executive Opinion Survey scores on transport infrastructure indicators in the Philippines, 2004-2010 (Source: World Economic Forum, Global Competitiveness Report, various issues)

network climbed during the mid-1990s, rising to $19.8 \%$ in 1998 , but then fell to $9.9 \%$ in 2002. The length of rail lines stagnated between 1990 and 2008: the country had $479 \mathrm{~km}$ of rail in the early $1990 \mathrm{~s}$, a number that increased to $491 \mathrm{~km}$ by 2004 and eventually fell back to $479 \mathrm{~km}$ by 2008 .

The Philippines also ranked relatively low (101st of 139 countries) in the 2010-2011 WEF Executive Opinion Survey in terms of the quality of electricity supply, garnering a score of 3.4 (the possible score ranges from 1 [insufficient] to 7 [sufficient and reliable]). Concerns over a looming power shortage or crisis in the country were evident in 2010 amid intermittent power outages, particularly in the southern part of the archipelago (Mindanao), as widespread droughts caused by El Nino — which resulted in receding water reservoirs in hydroelectric dams-coupled with poor maintenance work, have led to inadequate power supply. At that same time, the disruptive weather had resulted in surging peak demand (DOE 2010). Moreover, structural reforms in the power sector have faced bottlenecks, and not enough new power capacity has come online in the country. Obstacles to power sector reforms include delays in the privatization of the government's power generation assets-such as power plants, particularly those from the state-owned National Power Corporation-hampering the rehabilitation of these assets and limiting the participation of the private sector in the electricity supply industry.

Moreover, power supply in the Philippines is geographically concentrated in a few areas, further contributing to the problem of inadequate power capacity. In a recent assessment of the Philippines' power situation, the Department of Energy (DOE) of the Philippine government reported that: (i) In the country's Luzon 
region, the power generation capacity has been concentrated in the Northern and Southern areas, with relatively large power loads in Metro Manila and neighbouring provinces; (ii) Power generation capacity in the Visayas region has been concentrated in the Leyte-Samar grid; and (iii) In Mindanao, most of the power generation capacity is located in the Northern areas but the bulk of electricity demand comes from the Southern areas.

As electricity demand continues to increase (see Appendix 1, Fig. 14), there is an urgent need to create more energy-related infrastructure in order to increase the country's power generation capacity. Over 2010-2013, the DOE together with power firms plan to build four coal-fired plants across the archipelago. Furthermore, the DOE has projected that the Luzon, Visayas and Mindanao power grids would respectively need an additional capacity of 11,900 megawatts (MW), 2,150 MW and 2,500 MW of capacity by $2030 .^{2}$

Access to water seems to have marginally improved over the years in the Philippines (see Appendix 1, Fig. 15). The proportion of the overall population in the country with access to an improved water source has climbed gradually, from $84 \%$ in 1990 to $87 \%$ in $1995,88 \%$ in $2000,90 \%$ in 2005 and $91 \%$ in 2008. Urban dwellers generally have better access to an improved water source than those in rural areas. The share of the urban population with access to an improved water source remained unchanged at $93 \%$, while the situation improved consistently in rural areas from $76 \%$ in 1990 to $87 \%$ in 2008 .

Despite improved water access, there is still a need for the Philippine government to further expand water distribution and improve water infrastructure. The government has admitted that there are certain challenges in the water sector such as: water depletion in major cities, including Metro Manila and Metro Cebu; rampant water pollution; increasing demand for water; low willingness to pay for water; low cost recovery of investments; and institutional problems.

\section{Government Policy on Infrastructure}

The Philippine Infrastructure Public-Private Partnership (PPP) program is the flagship policy agenda of the government in promoting infrastructure development in the country. The PPP recognizes the private sector's role as a catalyst of growth and as an important source of infrastructure financing. Infrastructure projects covered by the PPP program include those that aim to develop the agri-business, educational, energy, environment, health, industry, information and communications technology, logistics, property, transportation, telecommunications and water supply sectors.

\footnotetext{
${ }^{2}$ Ibazeta (2010).
} 
Table 1 Breakdown of Philippine infrastructure investment (by sector, 2009-beyond 2013, billions of pesos)

\begin{tabular}{lrrrrrr}
\hline Sector & \multicolumn{1}{c}{2009} & \multicolumn{1}{c}{2010} & \multicolumn{1}{c}{2011} & \multicolumn{1}{c}{2012} & \multicolumn{1}{c}{2013} & Beyond 2013 \\
\hline Transportation & 123.8 & 247.6 & 133.2 & 102.2 & 63.6 & 171.9 \\
Power & 85.5 & 196.2 & 246.9 & 150.9 & 94.7 & 230.3 \\
Water & 36.5 & 68.8 & 68.2 & 112.2 & 49.6 & 179.2 \\
Telecommunications & 7.9 & 9.8 & 7.3 & 15.5 & 15.0 & 0.5 \\
Social infrastructure & 43.8 & 279.1 & 40.8 & 31.2 & 24.7 & 26.0 \\
Support to ARC's & 23.5 & 22.0 & 58.4 & 247.3 & 55.7 & 3.3 \\
Re-lending programs & 5.0 & 9.0 & 10.2 & 11.3 & 4.3 & 13.4 \\
Total & 326.0 & 832.6 & 564.9 & 670.7 & 307.6 & 624.7 \\
\% of GDP & 4.1 & 9.2 & 5.8 & 6.9 & 3.2 & 6.4 \\
\hline
\end{tabular}

Source: National Economic and Development Authority (NEDA) and authors' computation

Note: 2011 nominal GDP data is used to get the share of infrastructure investment for 2012, 2013, and beyond 2013

$A R C s$ agrarian reform communities, GDP gross domestic product

The Medium Term Philippine Development Plan (MTPDP) 2004-2010 reported that the Philippine government will prioritize transportation infrastructure-related projects that boost the country's trade and investments. These projects include construction of roads and railroads that will decongest the country's capital (Metro Manila), major highways, roads and airports connecting tourism hubs, and roll-on roll-off (RORO) ports. The government aims to boost infrastructure spending in the country through the Comprehensive and Integrated Infrastructure Program (CIIP). The CIIP anticipates that the private sector would bring PHP400.9 billion in infrastructure financing, with PHP214.4 billion in the transport sector, PHP112.3 billion in water supply, PHP70.7 billion in social infrastructure and PHP3.5 billion in telecommunications. ${ }^{3}$

Table 1 shows the annual sectoral breakdown of planned infrastructure investment in the Philippines starting in 2009 and through to 2013 and beyond. Total planned infrastructure spending in 2011 is $32.2 \%$ lower than in the previous year, at PHP564.9 billion (5.8\% of GDP); the power sector was expected to have the largest allocation at PHP246.9 billion (43.7\% of total), followed by the transportation sector at PHP133.2 billion (23.6\% of total). Infrastructure investments are planned to be $18.7 \%$ higher in 2012 on a year-on-year basis, at PHP670.7 billion (6.9\% of GDP), and the largest chunk of investments (36.9\%) in 2012 was to be targeted to government support for agrarian reform communities (ARCs). In 2013, the government plans lower infrastructure investments of PHP307.6 billion $(3.2 \%$ of

\footnotetext{
${ }^{3}$ Paderanga (2010).
} 
GDP), with the power sector receiving the greatest share of the total, at PHP94.7 billion (30.8\% of total). Beyond 2013, it is estimated that about PHP625 billion (6.4\% of GDP) will be spent on infrastructure, with power, water and transportation being the largest recipients.

In 2010, the Philippine government's expenditures (excluding interest payments and spending on financial services) totalled PHP1,379.3 billion, of which $36.3 \%$ were on goods and services from production sectors, $33.8 \%$ on social services, $24.5 \%$ on general public services and $5.3 \%$ on national defence. ${ }^{4}$ The largest single focus of public spending was education, at $17.4 \%$ of public spending (PHP240.6 billion), followed by transport and telecommunications infrastructure (12.6\%, PHP174.3 billion). However, public spending on health-related infrastructure and on electricity/energy-related infrastructure were both relatively small, respectively at $3.7 \%$ (PHP50.9 billion) and $1.3 \%$ (PHP17.8 billion).

\section{Philippine Poverty Profile}

Based on official accounts disseminated by the National Statistics Coordination Board (NSCB) of the Philippine government, the poverty incidence (estimated using per capita income data) among the Philippine households in 2009 was estimated at $26.5 \%$, which is higher than the previously estimated poverty incidences of $26.4 \%$ in 2006 and $24.9 \%$ in 2003. Philippine economic growth fluctuated during this period, with real GDP growth of $1.1 \%$ in $2009,5.2 \%$ in 2006 and $5.0 \%$ in 2003. More recently, in April 2013, the NSCB reported that the poverty incidence among the whole population for the first semester of 2012 stood at $27.9 \%$, somewhat lower than the 2009 and 2006 first semester figures of $28.6 \%$ and $28.8 \%$, respectively. Moreover, income inequality in the country declined somewhat during this period, with the Gini coefficient falling from 0.465 in 2003 to 0.458 in 2006 and slipping further to 0.448 in 2009.

\section{Snapshot of Philippine Poverty}

We now provide a description or characterization of poverty based on explicit subgroup characteristics in order to highlight the regional variation and urbanity

\footnotetext{
${ }^{4}$ Inclusive of interest payments (PHP276, 212.0 million) and payments for financial services (PHP6, 994.7 million), public expenditures of the Philippines in 2010 totalled PHP1, 662.5 billion.
} 


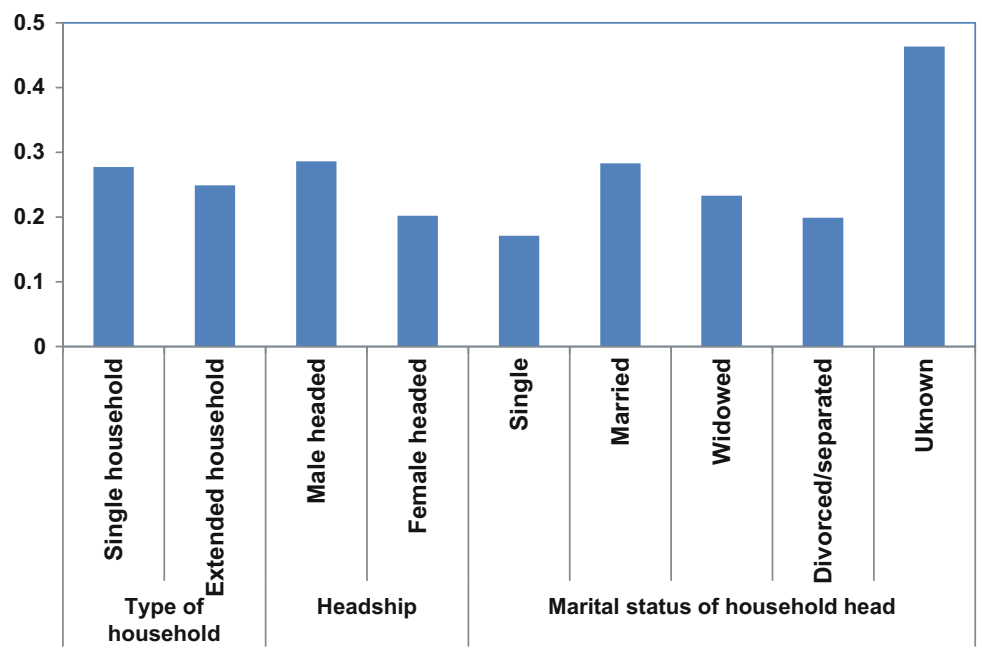

Fig. 2 Poverty incidence based on type of household, sex and marital status of household head (Source: Authors' computation based on Philippine FIES 2006 (overall))

differences of poverty estimates by using survey estimation techniques. ${ }^{5}$ In constructing profiles, we consider the following attributes: (1) headship; (2) economic activities of the household head which include occupation and class of work; (3) marital status of household head; and (4) the type of household.

We estimated the poverty incidence for each of the household attributes based on data from the 2006 Family Income and Expenditure Survey (FIES) (the full results are shown in the Appendix 2, Table 9). Figure 2 presents the poverty incidence by household type, and sex and marital status of the household head. It shows that single households or nuclear families have a higher poverty incidence $(27.7 \%)$ than extended households (24.9\%); this may be due to the fact that extended households have more access to resources, giving rise to relatively more reliable safety nets. This is consistent with the findings of Albert and Collado (2004) which were based on the 2000 FIES. We also find that roughly $29 \%$ of male-headed households are poor, whereas about $20 \%$ of female-headed households are poor. By marital status of the household head, the lowest poverty incidence is found among single-parent households at $17.1 \%$, followed by households whose head is divorced (19.9\%),

\footnotetext{
${ }^{5}$ We computed estimates by using the survey's total estimation module which allowed us to compute for the total number of poor and non-poor households. The sampling weights that we use pertain to probability weights assigned to respective households. The stratifying variable that we use combined information on the province and urban/rural residence.
} 
whereas households whose heads are married have a higher poverty incidence (28.3\%).

Estimates of poverty incidence by class of worker (household head) and number of household members employed are likewise presented in Table 9 in the appendix. The literature generally finds a strong relationship between poverty status and involvement in economic activities. Our results show that households are more likely to be poor when the head is self-employed and are less so if the head works for the government. Our calculations also show that households with heads working in the public sector have a lower poverty incidence compared with households whose heads are working in the private sector. This can be easily explained by the fact that, on average, civil servants earn more, and more stable, income than those working in the private sector. ${ }^{6}$ The incidence of poverty among self-employed household heads is higher than among those employed in the private sector. In fact, households whose heads are self-employed have the highest poverty incidence, at $34.7 \%$; this is somewhat expected since a significant portion of the workforce is employed in the informal sector, which is dominated by unincorporated businesses. Finally, households with eight employed members have a relatively lower poverty incidence than those with less than eight employed members.

\section{Methodology}

A combination of computable general equilibrium (CGE) and micro-simulation methodologies is employed to understand how public infrastructure investments impact on the Philippine economy. We now briefly present the models and underlying data.

\section{The CGE Model}

We employ a dynamic general equilibrium model developed by Dissou and Didic (2011) to trace the channels via which public infrastructure investments filter through the Philippine economy. To avoid repetitiveness, we only summarize the salient features of the model and refer the interested reader to Dissou and Didic (2011) for a more complete model specification. ${ }^{7}$ In general, the model assumes a

\footnotetext{
${ }^{6}$ However, we do not have evidence that private sector workers with comparable attributes relative to government workers have better compensation.

${ }^{7}$ For more details of the model, please see Dissou and Didic (2011).
} 
small open economy - consisting of households, firms and the government - that produces and consumes tradable and non-tradable goods and has access to the international capital market.

An important feature of this model is that it explicitly treats public capital as an input into the firms' production process, and thus allows us to quantify the growth and distributive effects of public infrastructure investments on the Philippine economy over time.

Public capital is assumed to be a pure public $\operatorname{good}^{8}$ and enters firms' production functions as an externality that enhances output. This is because the accumulated flows of public infrastructure investment generate positive externalities in the production of goods and services by firms. Although data limitations restrict the analysis to the effects of the public capital stock as a whole, productivity effects of public infrastructure are allowed to vary across industries. Firms in all industries make use of intermediate inputs, labour, physical capital and public capital to produce a composite output that can be sold in both domestic and international markets. However, public capital is a fixed input - as it is a decision variable at the discretion of the government rather than of the firm-while other inputs are controlled by the private sector.

The economic intuition behind the impact of public infrastructure on economic growth in the model is as follows. In a scenario with fixed public capital and increased supply of other inputs — such as labour, physical capital and intermediate inputs - the productivity of labour and physical capital would deteriorate, thereby hurting economic growth. For example, physical capital accumulation alongside labour supply growth can result in negative externalities such as traffic congestion and deteriorating infrastructure quality if not accompanied by higher investments in public infrastructures. In order to mitigate these negative effects on the productivity of private inputs and to spearhead economic growth, the stock of public capital must increase through investments in public infrastructures.

As shown in Fig. 3, gross output is determined via a three-stage process. The lowest stage involves the optimal determination of labour and private capital through a constant elasticity of substitution (CES) function. The CES labourprivate capital aggregate is then combined with public capital through another CES function to form a composite value added. In spite of the CES aggregator formulation, the stock of public capital is a fixed factor with endogenous rates of return reflecting its marginal product. Note that public capital is not a decision variable for the firm since public capital stocks are accumulated through public sector infrastructure investments. Finally, gross output is determined by combining the composites of value added and intermediate inputs (a Leontief function of individual intermediate inputs) through another CES function.

\footnotetext{
${ }^{8}$ As a pure public good, services derived from public capital are not subject to congestion.
} 


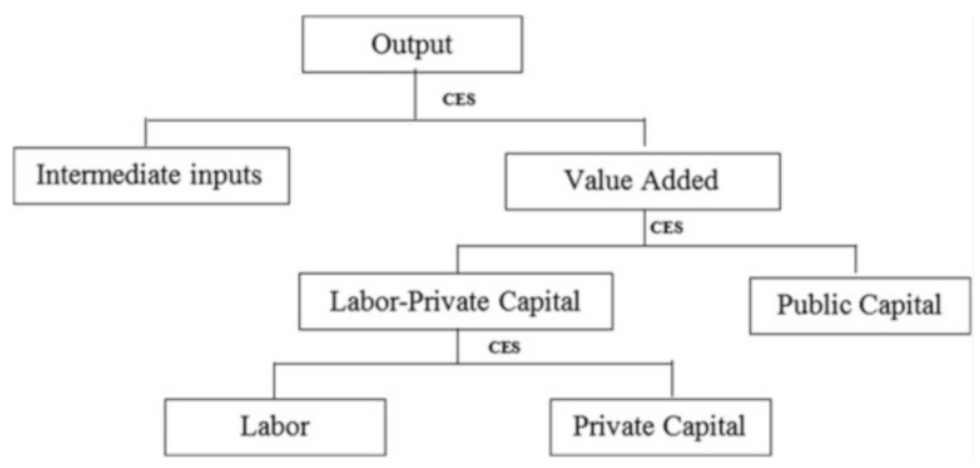

Fig. 3 Production structure

Another salient feature of the model is that it accounts for firm and household heterogeneity. Households are divided into two types according to their access to credit markets: (a) constrained (myopic) households do not have access to credit markets. These households consume out of their current income, and at the same time save a constant and strictly positive fraction of their disposable income (Keynesian savings behaviour); and (b) non-constrained (forward-looking) households have access to credit in the capital market, where they can borrow and lend at a fixed world interest rate. These households are thus able to smooth consumption over time. Regardless of the household type, we assume that household labour supply is perfectly inelastic, implying that households do not consider leisure as part of their labour supply decision. Household income sources are: wages, capital income (returns from both private and public capital) and transfers from the government and from the rest of the world. Finally, all households consume on the basis of a constant elasticity of substitution (CES) function.

Firms are also classified into two types according to their access to the credit market. Non-constrained firms have access to capital markets where they can borrow and lend at a fixed world interest rate and are owned by non-constrained households. These firms determine their optimal levels of inputs and outputs through intertemporal optimization. Constrained firms do not have access to capital markets and are exclusively financed by constrained households who use their savings to purchase the capital stock of these firms. In contrast to non-constrained firms, constrained firms only maximize current profits. The government collects income taxes directly on the labour income of both non-constrained and constrained households and from the dividends of non-constrained households.

Real government spending on commodities is exogenous but grows overtime as a function of population growth and technological progress. The current public infrastructure-to-GDP ratio is exogenous. We treat this ratio as a policy variable that can be modified to perform simulations in relation to increased public infrastructure. Government savings is held fixed to ensure that the public sector cannot increase its debt over time. Higher public investment in infrastructure is either 
financed by a uniform increase in production tax rates imposed on all firms or through an increase in foreign financing, with payments to the latter being part of foreign debt service payments in each period. The labour market behaves in a neo-classical manner and wages adjust to ensure equilibrium in labour markets. Similarly, commodity prices adjust to maintain equilibrium in the goods markets. Total investment is financed by total savings: investment in constrained firms is financed from the savings of constrained households; while dividends paid by non-constrained firms to non-constrained households are net of investment expenditures. In addition, the transversality condition imposed on asset holdings ensures that the country cannot continuously increase its foreign debt, i.e., any increase in debt today must be paid for by future increases in the current account balance. Finally note that the fixed government savings provide the macro closure.

\section{CGE Data and Parameters}

The model uses an aggregated version of the latest available unofficial social accounting matrix (SAM) for the Philippines (Cororaton and Corong 2009) as its principal database. There are 12 sectors in the model: (1) crops and livestock; (2) other agricultural products; (3) food, alcoholic beverages, and tobacco; (4) mining; (5) paper and wood; (6) petrochemicals; (7) textiles and garments; (8) heavy manufacturing; (9) light manufacturing; (10) other manufacturing; (11) public services; and (12) other services. Three sectors are assumed to be comprised of constrained firms: other agriculture, other manufacturing and other services; the rest are comprised of non-constrained firms.

Table 2 presents the basic structure of the Philippine economy in the base scenario, following the country's SAM. Of the 12 sectors, the light manufacturing sector is observed to contribute the largest share to the country's value added and to total investment, exports and imports. The other services sector accounts for the largest share of final consumption.

Table 3 summarizes the CES elasticities for the production structure illustrated in Fig. 6. Due to an absence of econometric estimates, we assume conservative elasticities taken from estimates in the literature on developing countries. Note that, although the assumed production elasticity of substitution found in the first three columns of Table 3 are the same for all sectors, their relative shares are different. Relative shares are of greater importance than elasticity values as the simulation results are driven more by the structure of the economy than by the differences in the choice of elasticity parameters.

Similarly, the last two columns of Table 3 show the elasticities for the CES-Armington function (substitution between imports and domestic sales) and the CET function which reflects substitution between exports and domestic sales. These values were taken from the GTAP database. 
Table 2 Characteristics of Philippine economy (based on 2000 Philippine SAM)

\begin{tabular}{llllllll}
\hline & $\begin{array}{c}\text { Value } \\
\text { added }\end{array}$ & Consumption & Investment & Government & Exports & Imports \\
\hline Crops and livestock & 4 & 3.5 & 4.5 & 0 & 1.2 & 1.9 \\
Other agriculture & 0 & 3.2 & 0.1 & 0 & 0.8 & 0 \\
$\begin{array}{l}\text { Food, beverage and } \\
\quad \text { tobacco processing }\end{array}$ & 2 & 19.9 & 0.4 & 0 & 3.6 & 4.1 \\
Mining & 0.2 & 0.1 & 0 & 0 & 0.4 & 9 \\
Paper and wood & 1.7 & 0.7 & 0.3 & 0 & 2.1 & 1.8 \\
Petrochemical & 1.1 & 3.7 & 0.2 & 0 & 2.6 & 7.4 \\
Textiles and garments & 1.1 & 3.2 & 0.2 & 0 & 9.5 & 5.2 \\
Heavy manufacturing & 1.4 & 0.1 & 0.6 & 0 & 2.7 & 4.7 \\
Light manufacturing & 85.3 & 3 & 48.6 & 0 & 59.5 & 47.9 \\
Other manufacturing & 3.2 & 1 & 2.7 & 0 & 3 & 2 \\
Public services & 0 & 0.1 & 0 & 100 & 0.1 & 0 \\
Other services & 0 & 61.6 & 42.4 & 0 & 14.6 & 16 \\
\hline
\end{tabular}

Source: Authors' computations

SAM social accounting matrix

Table 3 Parameters for CGE model (based on 2000 Philippine SAM)

\begin{tabular}{|c|c|c|c|c|c|}
\hline & $\begin{array}{l}\text { Gross } \\
\text { output }\end{array}$ & $\begin{array}{l}\text { Value } \\
\text { added }\end{array}$ & $\begin{array}{l}\text { Labour-private } \\
\text { capital }\end{array}$ & $\begin{array}{l}\text { CES } \\
\text { Armington }\end{array}$ & CET \\
\hline Crops and livestock & 0.5 & 0.4 & 0.4 & 2.3 & 2.3 \\
\hline Other agriculture & 0.5 & 0.4 & 0.4 & 2.8 & 2.8 \\
\hline $\begin{array}{l}\text { Food, beverage and tobacco } \\
\text { processing }\end{array}$ & 0.5 & 0.4 & 0.4 & 2.3 & 2.3 \\
\hline Mining & 0.5 & 0.4 & 0.4 & 2.8 & 2.8 \\
\hline Paper and wood & 0.5 & 0.4 & 0.4 & 2.1 & 2.1 \\
\hline Petrochemical & 0.5 & 0.4 & 0.4 & 1.9 & 1.9 \\
\hline Textile and garment & 0.5 & 0.4 & 0.4 & 2.3 & 2.3 \\
\hline Heavy manufacturing & 0.5 & 0.4 & 0.4 & 2.8 & 2.8 \\
\hline Light manufacturing & 0.5 & 0.4 & 0.4 & 3.0 & 3.0 \\
\hline Other manufacturing & 0.5 & 0.4 & 0.4 & 2.8 & 2.8 \\
\hline Public services & 0.5 & 0.4 & 0.4 & 1.9 & 1.9 \\
\hline Other services & 0.5 & 0.4 & 0.4 & 2.6 & 2.6 \\
\hline
\end{tabular}

Source: Authors' computations

SAM social accounting matrix

\section{Microsimulation Module}

A top-down CGE microsimulation procedure is employed by using the results of the CGE simulations as inputs into a microsimulation module in order to assess the distributive impacts of higher public infrastructure investments. The microsimulation module, which is based on Cockburn, Duclos and Tiberti (2011), uses the 2006 Family Income and Expenditure Survey (FIES) of the Philippines.

For brevity, we only summarize the microsimulation procedure (for details see Cockburn et al. 2011). Per capita consumption in real terms for the base year and 
the simulation periods is the variable of interest for estimating poverty and inequality changes across the different scenarios. According to the methodology followed in this study, this variable is affected by the change in consumer prices as well as in household revenues, here corresponding to incomes from wage and selfemployment activities. Consistently with the CGE model, we also took into account the different marginal propensity to consumption for constrained and non-constrained households.

Initially, the FIES is processed to classify constrained and non-constrained households. A logit model specifies the probability of being a non-constrained household ( $\mathrm{Y}_{\mathrm{i}}=1 ; \mathrm{Y}_{\mathrm{i}}=0$ if constrained), which is defined as: has access to formal credit institutions, has saved or has a savings account. The logit model shown in Eq. 1 estimates the probability that a given household $h$ is non-constrained $\left(p_{h, n c}\right)$. By implication, the complement of $p_{h, n c}$ gives the probability that a given household $h$ is constrained $\left(p_{h, c}\right)$.

$$
\operatorname{Logit}\left(\pi_{h}\right)=\alpha+\beta_{v} X_{h}+\varepsilon_{h} \text { with } \pi_{h}=E\left(Y_{h} \mid X_{h}\right)
$$

where vector $X_{h}$ includes the $V$ community and household socio-economic characteristics of household $h$ : household's region and urban/rural residence, whether the household head receives a fixed payment from work activities, the occupational category the household head belongs to, the natural logarithms of real per capita household consumption, household size, household head's gender and age, as well as the educational level of the household head and the household head's age squared.

Passing to labour activities, we considered one single category of worker (which is perfectly mobile across all sectors) and we made the hypothesis of full employment. This is in accordance with CGE model's hypotheses. As for revenues, revenues for wage workers that reported missing incomes have been estimated by a standard Heckman selection approach. Then, the change in the wage rate as predicted by the CGE model has been used to simulate the variation in the wage component across the different scenarios. Changes in revenues from selfemployment activities (included the component for own-consumption) were derived from the variations in the sectoral (value of the) value-added as simulated by the macro model. It is noteworthy here that the CGE results (concerning the quantities variables) are provided in terms of productive worker, then taking into account the change in population, labour force and technology over time.

To observe changes in household consumption levels following variations in the prices of goods and household income, the nominal consumption for each good is converted into real terms. Using a Cobb-Douglas utility function, which lays on the hypothesis of fixed budget share, real or equivalent per capita consumption is:

$$
e_{h, d, t}=\frac{y_{h, d, t}}{\Gamma_{h, d, t}} \text { with } \Gamma_{h, d, t}=\prod_{k=1}^{K}\left(\frac{p_{k, d, t}}{p_{k, D, 0}}\right)^{w_{h, d, k}}
$$


where $y_{h, d . t}$ is the total nominal per capita expenditures of each household $h$ living in district $d$ at time $t ; \Gamma_{h, d, t}$ is the household-specific consumer price deflator which takes into account both spatial (by comparing district $d$ to the reference cluster $D$ here, the capital region NCR) and temporal (by comparing time $t$ to the reference time 0 ) price differences; $p_{k, D, 0}$ is the reference unit price, which corresponds to the price of good $k$ at time 0 estimated in the reference district $D ; p_{k, d, t}$ is the unit price at time $t$ for good $k$ in cluster $d ; w_{h, d, k}$ is the budget share for good $k$ by household $h$ in district $d$. As for the economic sectors, we mapped the categories of consumption commodities in the underlying micro and macro data and then aggregated by nature of goods in order to have the same type of aggregates in the two models.

To be consistent with the household classifications in the CGE model, the microsimulation procedure takes into account the differences in savings and consumption of all households, particularly non-constrained households which can change their savings rate over time (in contrast to constrained households whose savings rate remains fixed). Nominal per capita consumption for a household $y_{h, d, t}$ at time $t$ is calculated as:

$$
y_{h, d, t}=y_{h, d, t=0}+\sum_{k=1}^{j}\left(\Delta R_{h, d, t}^{k} p_{h, n c}\left(1-s_{n c, t}\right)+\Delta R_{h, d, t}^{k} p_{h, c}\left(1-s_{c}\right)\right)
$$

where $y_{h, d, t}$ is defined as the sum of per capita consumption of household $h$ in the base year $\left(y_{h, d, t=0}\right)$ and the per capita changes in the $k$ revenue components $(R)$, namely wage and non-wage incomes. As already stated, changes in these sources are taken from the CGE simulation results and plugged into the micro module. As defined by Eq. 3, changes in the revenue sources are weighted by the probability of household $h$ being non-constrained $p_{h, n c}$ (and the complementary situation of being constrained). Only the shares devoted to consumption are retained for consumption: $\left(1-s_{n c, t}\right)$ for non-constrained households and $\left(1-s_{c}\right)$ for constrained households, where $s_{n c, t}$ and $s_{c}$ are the saving rates for the two types of households.

Poverty effects are measured using the Foster-Greer-Thorbecke (FGT) $P \alpha$ class of additively decomposable measures (Foster et al. 1984). Let $\mathrm{z}_{\mathrm{D}, 0}$ be the real poverty line, that is, a line measured in terms of the reference prices $\mathbf{p}_{D, 0}$. The FGT family index is then defined as:

$$
P_{\alpha}(z)=\frac{1}{\mathbf{N}} \sum_{h=1}^{H} \rho_{h, d} n_{h, d}\left(\frac{z_{D, 0}-e_{h, d, t}\left(\mathbf{p}_{k, D, 0}, \mathbf{p}_{k, d, t}, y_{h, d, t}\right)}{z_{D, 0}}\right)_{+}^{\alpha}
$$

where $f_{+}=\max (0, f), \mathbf{N}$ is the number of households in the survey (and corresponds to the sum of the sampling weights), $n_{h, d}$ is the size of the household $h, \rho_{h, d}$ is the sampling weight of $h$, and $\alpha$ is a parameter that captures the "aversion to poverty" or the distribution sensitivity of the poverty index.

The FGT poverty measure depends on the values that the parameter $\alpha$ takes. We calculate the poverty headcount for $\alpha=0$. The poverty headcount is the proportion of the population that falls below the poverty line. When $\alpha=1$, the poverty gap 
indicates how far the poor are from the poverty line on average. Finally, when $\alpha=2$, the severity of poverty is measured as the squared average distance of income of the poor from the poverty line. The severity index is more sensitive to the distribution among the poor because the poorest of the poor in the population are weighted more heavily.

Inequality is calculated using the Gini coefficient, which is the most commonly used measure of inequality. It computes the average distance between cumulative population shares and cumulative income shares (Duclos and Araar 2006). The Gini coefficient is calculated as:

$$
\text { Gini } \equiv I(2)=\int_{0}^{1}(p-L(p)) \kappa(p ; 2) d p
$$

where $L(p)$ is the cumulative percentage of total income held by the cumulative proportion $p$ of the population (ranked by increasing income) and $k$ represents the percentile-dependent weights.

\section{Policy Experiments}

Using the CGE model described in the section "The CGE Model," we conduct two policy experiments to assess the potential effects of higher public investment in infrastructure financed by: (1) international lending with a concessional interest rate of $6 \%$; and (2) higher production taxes. In order to stay within reasonable limits of attainable government policies we simulate a $25 \%$ permanent increase in the public infrastructure expenditure-to-GDP (PIE-to-GDP) ratio relative to the baseline. This increase is sufficient to achieve the government's minimum PIE-to-GDP ratio target of $5 \%$.

As mentioned in the section "Public Infrastructure", a contentious empirical issue is the estimation of the elasticity of output to public capital. Given the absence of econometric estimates for the Philippines, we assume a conservative exogenous elasticity of output to public capital of $0.15 \%$ - a lower-end estimate that is consistent with most empirical studies. This conservative value was chosen to account for concerns that large estimates of the output elasticity of public capital could emanate from high public investment (as a proportion of GDP)—as corruption tends to inflate public investments, from unproductive uses in public capital and from the composition of public capital. However, we undertake sensitivity analysis to determine the robustness of the estimated economic and poverty impacts to changes in the assumed elasticity of output to public capital.

Other variables that are exogenously determined in the model include the annual population growth rate $(1.8 \%)$, the foreign concessional lending rate $(6 \%)$, and the depreciation rate of the public and private capital stocks (15\%, respectively). Using base year values from the SAM, in conjunction with exogenously given parameter 
values and the transvertality condition, we calibrate and solve the dynamic CGE model to reproduce the baseline path of the economy over a 50-year time horizon. The Business as Usual (BaU) scenario is then used to make comparisons with the counterfactual simulation results. Note that, in the $\mathrm{BaU}$, all real variables are expressed in efficiency units and all prices are held constant.

\section{Simulation Results}

We analyze the economy-wide effects of higher public investment in infrastructure at the aggregate and the sectoral level encompassing three time frames: the immediate period (first year), the short-run (fifth year) and the long-run (twentieth year). Since investments made in the current year only become fully operational in the following year, we first discuss the demand-side effects of an increase in the PIE-toGDP ratio in the immediate period. We then discuss the demand-side and the supply-side effects arising in the short-run and the long-run. Note that all results are presented as percentage deviations from the economy's baseline trajectory. Presenting results this way allows us to isolate the economy-wide effects arising from higher public investment.

\section{Scenario 1: 25 Percent Increase in the PIE-to-GDP Ratio (International Financing)}

Macroeconomic effects: The macroeconomic results of scenario 1-a $25 \%$ increase in the PIE-to-GDP ratio financed by international lending at concessional interest rates-are shown in the first three columns of Table 4. An increase in public infrastructure investment financed by international borrowing immediately leads to real exchange rate appreciation (1.6\%), and thereby improves the purchasing power of the Philippine economy.

As a result, in the first year, imports rise by $2.6 \%$, as the appreciation of the real exchange rate immediately induces substitution away from domestically produced consumer and capital goods to the relatively cheaper imported consumer and capital goods. The appreciation of the real exchange rate further leads to a significant reduction in exports $(2.8 \%)$ in the first period, as they become relatively more expensive in the international market.

At the same time, total investment increases by $6.4 \%$ which is 1.4 percentage points more than in the scenario where an increase in the production tax finances higher public infrastructure expenditures. Higher total investment in the current scenario in the immediate period is primarily due to an expansion in private investment. In fact, in the current scenario, private investment rises by $0.8 \%$ in the first year following increased public investment in infrastructure, while it falls by $0.6 \%$ in the scenario where production taxes finance higher public investment in 
Table 4 Macro-economic results (percent deviations from baseline)

\begin{tabular}{|c|c|c|c|c|c|c|}
\hline & \multicolumn{3}{|c|}{ International financing } & \multicolumn{3}{|c|}{ Production tax financing } \\
\hline & First & $\begin{array}{l}\text { Short } \\
\text { run }\end{array}$ & $\begin{array}{l}\text { Long } \\
\text { run }\end{array}$ & First & $\begin{array}{l}\text { Short } \\
\text { run }\end{array}$ & $\begin{array}{l}\text { Long } \\
\text { run }\end{array}$ \\
\hline Real GDP & -0.1 & 1.5 & 2.9 & -0.2 & 0.9 & 2.0 \\
\hline Wage rate & 1.0 & 3.6 & 6.5 & -1.0 & 1.5 & 4.1 \\
\hline Price of investment good & 1.0 & 0.6 & 0.2 & 0.4 & 0.2 & 0.0 \\
\hline Total investment & 6.4 & 7.7 & 8.2 & 5.2 & 6.6 & 7.1 \\
\hline Public investment & 25.6 & 27.1 & 28.7 & 25.2 & 26.5 & 27.8 \\
\hline Private investment & 0.8 & 2.0 & 2.3 & -0.6 & 0.9 & 1.2 \\
\hline Constrained & 1.4 & 1.7 & 1.9 & -0.5 & -0.2 & 0.1 \\
\hline Non-constrained & 0.5 & 2.3 & 2.5 & -0.6 & 1.5 & 1.8 \\
\hline Total household consumption & 2.2 & 2.5 & 2.7 & 0.2 & 0.4 & 0.6 \\
\hline Constrained & 2.4 & 2.3 & 2.0 & -0.1 & 0.0 & 0.1 \\
\hline Non-constrained & 1.9 & 2.7 & 3.3 & 0.6 & 0.8 & 1.1 \\
\hline Total exports & -2.8 & -0.7 & 2.0 & -1.2 & 1.0 & 3.5 \\
\hline Total imports & 2.6 & 3.0 & 3.5 & 1.0 & 1.9 & 2.5 \\
\hline Real exchange rate ${ }^{a}$ & -1.6 & -0.9 & -0.5 & -0.6 & -0.5 & -0.4 \\
\hline Foreign saving & 0.9 & 0.4 & -0.3 & 0.8 & 0.4 & -0.2 \\
\hline Total capital stock ${ }^{\mathrm{a}}$ & 0.0 & 3.8 & 8.2 & 0.0 & 3.3 & 7.2 \\
\hline Public capital stock ${ }^{\mathrm{a}}$ & 0.0 & 13.5 & 27.5 & 0.0 & 13.3 & 26.6 \\
\hline Private capital stock ${ }^{\mathrm{a}}$ & 0.0 & 0.7 & 2.1 & 0.0 & 0.1 & 1.0 \\
\hline Constrained $^{\mathrm{a}}$ & 0.0 & 0.8 & 1.8 & 0.0 & -0.2 & 0.1 \\
\hline Non-constrained $^{\mathrm{a}}$ & 0.0 & 0.7 & 2.3 & 0.0 & 0.3 & 1.6 \\
\hline $\begin{array}{l}\text { Disposable income of constrained } \\
\text { households }\end{array}$ & 2.4 & 2.3 & 2.0 & -0.1 & 0.0 & 0.1 \\
\hline Labour income & 1.0 & 3.6 & 6.5 & -1.0 & 1.5 & 4.1 \\
\hline Capital income & 2.7 & 4.3 & 5.3 & -0.1 & 2.0 & 3.5 \\
\hline Government revenue & 8.4 & 9.6 & 10.9 & 6.9 & 8.3 & 9.6 \\
\hline Increase in production tax rate $(\%)$ & - & - & - & 27.0 & 24.9 & 22.4 \\
\hline $\begin{array}{l}\text { Additional international borrowing ( } \% \text { of } \\
\text { GDP) }\end{array}$ & 1.1 & 1.1 & 0.9 & - & - & - \\
\hline
\end{tabular}

Source: Authors' computation based on simulation results

${ }^{\mathrm{a}} \mathrm{A}$ positive sign indicates a depreciation of the real exchange rate

infrastructure. Hence, in the absence of an increase in production taxes, domestic firms are able to increase their profitability through higher capital goods production and higher accumulation of the private capital stock.

Furthermore, in the first period, the price of investment goods rises by $1 \%$-the highest increase of all periods considered in this scenario-because the productivity-enhancing effects of public infrastructure investments do not start to materialize until after the first year. Recognizing that increasing productivity arising from public infrastructure investment will lead to higher returns on investment in the future, non-constrained firms, in the first year, increase their level of investment by less than constrained firms $(0.5 \%$ vs. $1.4 \%)$.

As well, total household consumption increases by $2.2 \%$ in the first period, which is 2 percentage points more than in the scenario where production taxes 
finance increased public infrastructure investment. This is because consumption of both constrained and non-constrained households rises by $2.4 \%$ and $1.9 \%$, respectively. Two factors drive this result. First, the appreciation of the real exchange rate makes imported goods relatively cheaper, thereby inducing higher consumption. Second, higher household income arising from increasing returns to labour and capital provides an additional boost to household consumption.

However, in the first period, real GDP falls by $0.1 \%$ as the negative demand-side effects, at least in the immediate period, outweigh the positive demand-side effects of increased public infrastructure investment. Namely, the increases in private investment and household consumption experienced in the first year following higher public infrastructure investment are not sufficiently high enough to offset the stronger demand for imported goods and the considerable decline in exports. However, as a result of increased private investment and household consumption, the magnitude of the fall in the real GDP in the first period is lower than in the scenario where public infrastructure investment is financed by increased production taxes.

The positive, demand-side effects of higher public infrastructure investment strengthen in the short-run and the long-run as a result of ongoing private capital accumulation and improving productivity. In fact, when public infrastructure investment is financed by international borrowing, the economy is able to accumulate more private capital stock than in the case where this investment is financed by production taxes. Specifically, the total stock of private capital expands by $0.7 \%$ and $2.1 \%$, respectively in the short-run and the long-run in the current scenario, compared with $0.1 \%$ and $1 \%$ in the production tax scenario.

The disposable income of constrained households rises further in the short and the long-run, respectively by 2.3 and $2 \%$. This is largely due to the increase in these households' labour income (which rises by $3.6 \%$ in the short-run and by $6.5 \%$ in the long-run) and to an increase in their capital income (which rises by $4.3 \%$ in the short-run and $5.3 \%$ in the long-run). Higher incomes in turn lead to higher total household consumption, which grows by $2.5 \%$ and $2.7 \%$ over the short-run and the long-run.

Investments by constrained firms rise by $2 \%$ in the short-run and by $2.3 \%$ in the long-run, while investments by non-constrained firms increase by $3.8 \%$ and $8.2 \%$ over these time frames. Similarly, total investment in the short and the long-run grows by more in this scenario $(7.7 \%$ and $8.2 \%)$ than in the production tax scenario, as higher public investment is complemented by a rise in private investment.

Over time, the stronger real exchange rate appreciation resulting from the continuous inflow of international financing results in slower export growth and accelerated import growth (See Fig. 4). Although exports eventually recover due to the productivity-enhancing effects of additional public infrastructure, long-run potential export growth is somewhat lower than observed in the baseline. Heightened import demand and weakened exports demand are the primary reasons behind a deteriorating trade balance over time, which is exactly opposite to the situation observed in the production tax financing scenario. Nevertheless, public 


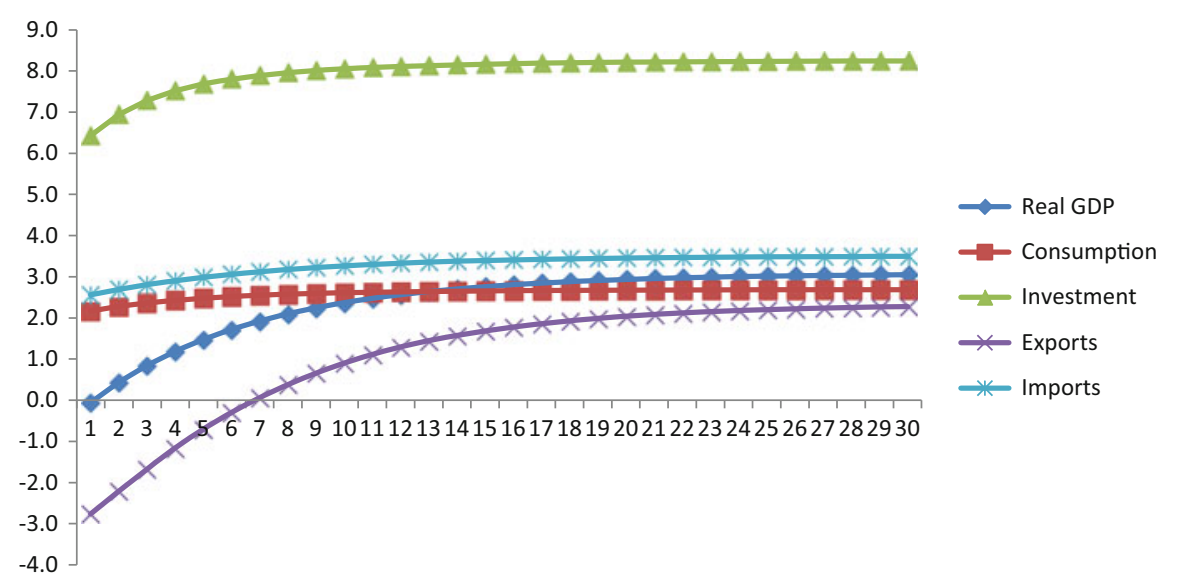

Fig. 4 GDP: demand side effects (international financing) (Source: Authors' computation based on simulation results)

infrastructure investment when financed by international lending still exhibits stronger positive economic effects over time, as reflected by the increase in real GDP in the short-run (1.5\%) and the long-run $(2.9 \%)$ than when it is financed by increased production taxes (Fig. 4).

Sectoral effects: We now analyze the sectoral effects of a $25 \%$ rise in the PIE-to-GDP ratio financed by international lending (Table 5). Exports fall in every sector in the immediate period (by at least $1.1 \%$ in the petro-chemicals sector and by at most $6.4 \%$ in the other manufacturing sector) as the appreciated real exchange rate leads to a loss in all sectors' competitiveness in the international market. Similarly, in the first period, imports increase substantially in every sector (by at least $0.3 \%$ in the mining sector and by at most $5.1 \%$ in the other manufacturing sector), as domestic consumers substitute domestic goods for cheaper imported products. The real exchange rate appreciation, together with stronger demand for imported capital goods, boosts imports in the light manufacturing, heavy manufacturing and construction services sectors since these sectors provide inputs for (increased) public investment.

In the absence of a distortionary production tax, output expands in the crops/ livestock, other agriculture, food processing, petrochemical and other services sectors $(0.7 \%, 0.3 \%, 0.6 \%, 0.1 \%$ and $0.5 \%$ respectively) in the immediate period following increased public infrastructure investment. Unfortunately, this is not the case for the textiles, light manufacturing, heavy manufacturing and other manufacturing sectors. In these sectors, output contracts in the first period due to the appreciation of the real exchange rate which makes imported capital goods (light and heavy manufacturing) relatively cheaper, causing domestic producers of these products to lose their competitiveness in the first year. Compared with the case 







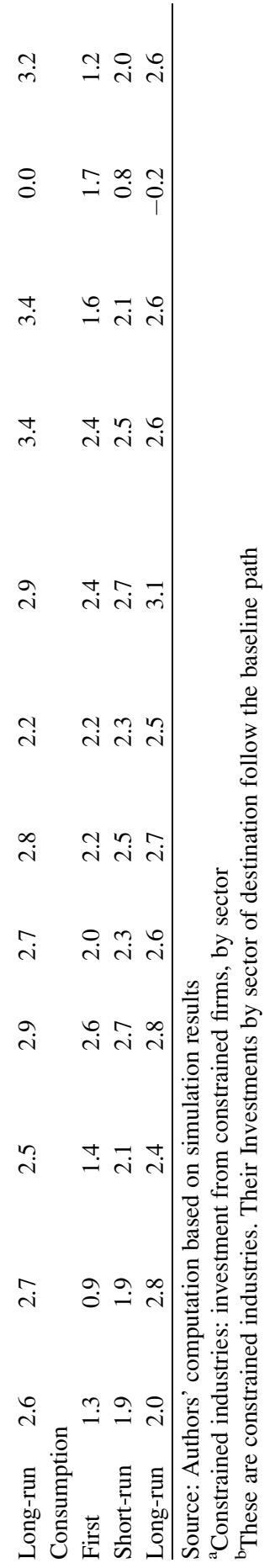




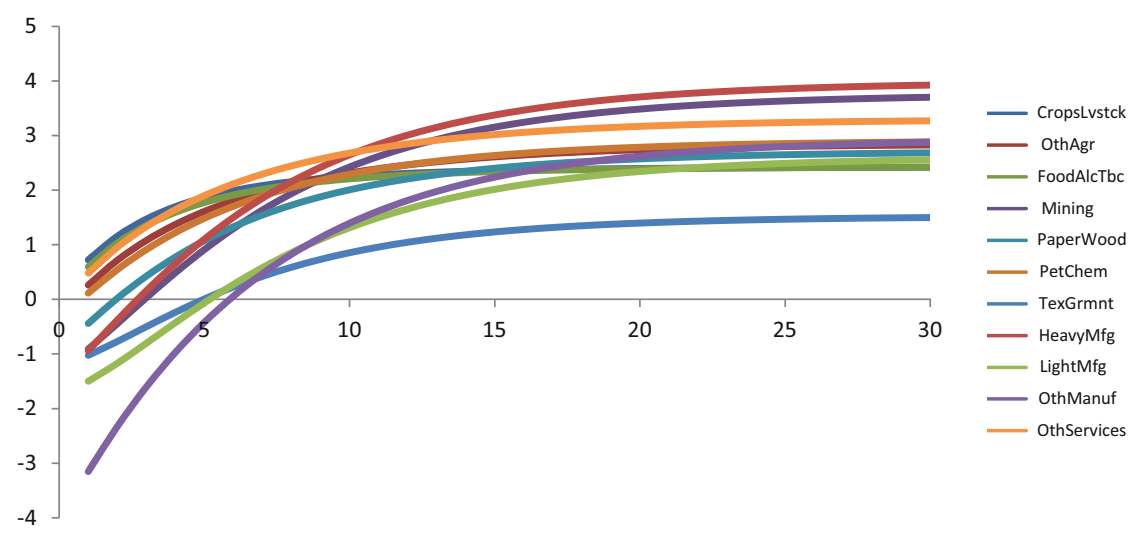

Fig. 5 Effects on output, by sector (international financing) (Source: Authors' computation based on simulation results)

where higher production taxes finance increased public infrastructure investment, total demand for goods and services from all sectors rises substantially. This is because of the stronger demand for cheaper imports and the effect of producers shifting towards the domestic market following exchange rate appreciation. This effect persists in the short-run and the long-run.

The long-run supply-side effects of higher public investment resulting from capital accumulation and improved productivity are felt by producers across the entire economy (See Fig. 5). Moreover, the increase in output across sectors is more or less similar given public infrastructure investment financed by international borrowing compared with that of production tax financing.

Over time, the positive spillover effects of higher public infrastructure investment enhance the competitiveness of domestic producers in the international market, supporting their export recovery (See Fig. 6). This contrasts with the results observed in the case of tax-financed public infrastructure investment. In that case, exports in the food processing sector and the petrochemical sector do not recover, even in the long-run. Instead, imports continue to outpace exports in the long-run due to the persistently higher real exchange rate (See Fig. 7).

As in the case where increased production taxes finance additional public infrastructure investment, all sectors experience an increase in investment in the long-run. Being an important producer of capital goods, heavy manufacturing registers an important expansion of investment in the short run (1.4\%) as well as in the long-run (2.6\%), resulting in substantial output and export growth over these time frames. Overall, public investment financed by international financing benefits 


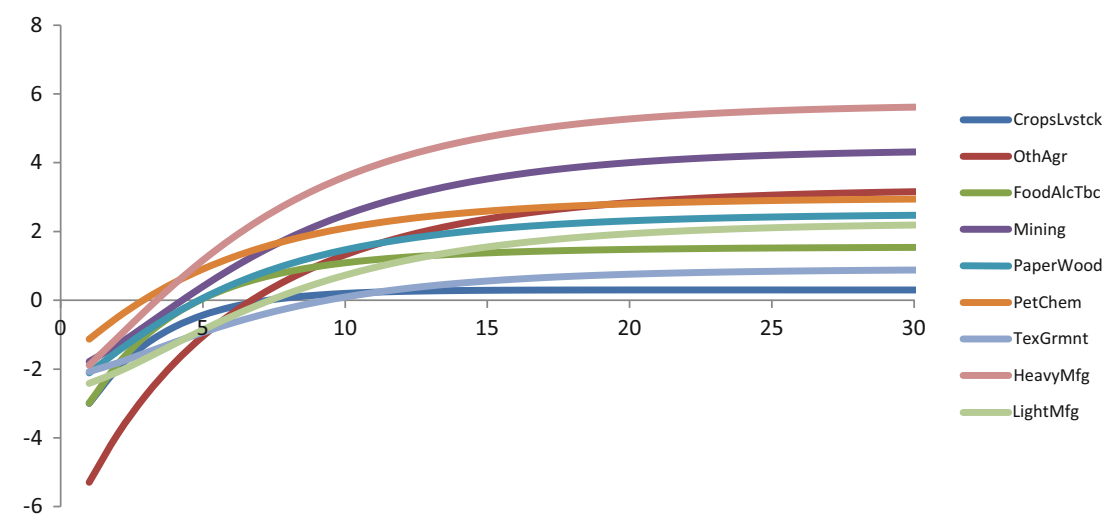

Fig. 6 Effect on exports, by sector (international financing) (Source: Authors' computation based on simulation results)

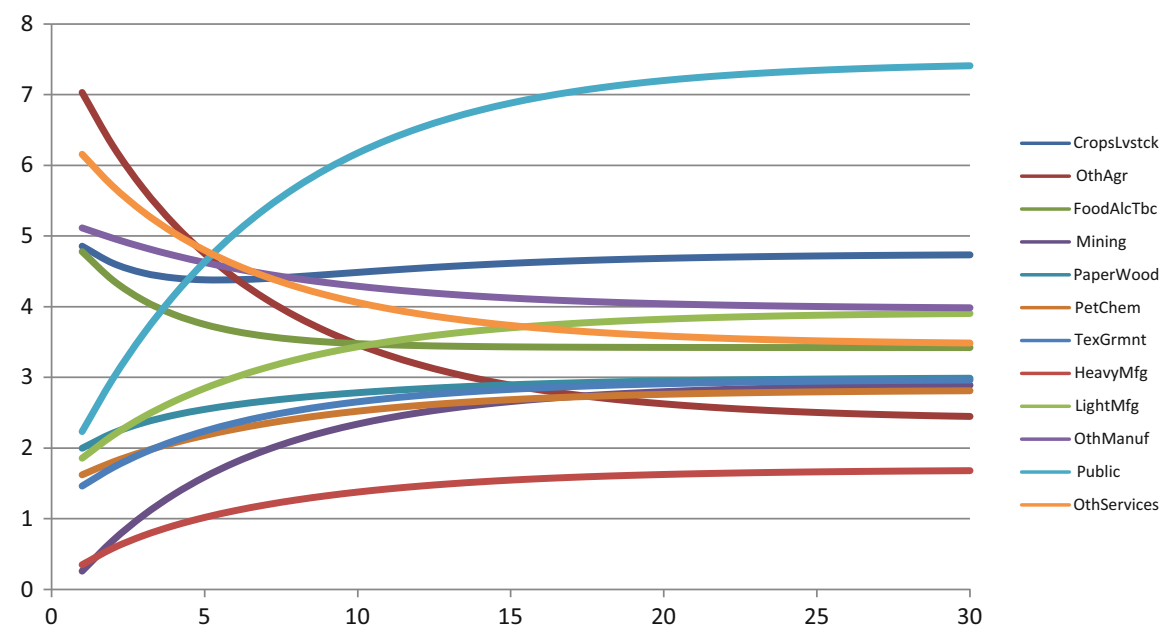

Fig. 7 Effect on imports, by sector (international financing) (Source: Authors' computation based on simulation results)

all sectors almost equally in terms of output expansion in the long-run. The reallocation of factors from the agricultural sector towards the heavy and light manufacturing sectors that is observed in the tax-financing case is absent in the current scenario. 


\section{Scenario 2: 25 Percent Increase in PIE-to-GDP Ratio (Production Tax Financing)}

Macroeconomic effects: The macro-economic results of scenario 2-a $25 \%$ increase in the PIE-to-GDP ratio financed by higher production taxes-are shown in the last three columns of Table 4 . Total investment in the first year increases by $5.2 \%$, bolstered by the $25 \%$ increase in public infrastructure investment. A slight reduction in total private investment of $0.6 \%$ is indicative of the presence of a crowding-out effect. This immediate, negative crowding-out effect of tax-financed public infrastructure investment arises as a result of higher prices of investment goods $(+0.4 \%)$ and the higher production tax rate imposed on all firms. Total private investment thus falls: non-constrained firms decrease their level of investment marginally more $(-0.6 \%)$ than constrained firms $(-0.5 \%)$.

Furthermore, in the first period, imports rise by $1.0 \%$ as higher public investment boosts demand for imported capital goods which become relatively less expensive than domestically produced goods. At the same time, exports fall by $1.2 \%$ because domestic firms are less competitive on international markets due to the higher cost structures associated with higher production taxes. The combination of lower exports and higher imports results in real exchange rate appreciation of $0.6 \%$ and a deterioration in the trade balance.

Surging demand for imported goods combined with falling exports and decreased private investment lead to a $0.2 \%$ fall in real GDP in the first period following an increase in tax-financed public infrastructure investment. In fact, the rate of taxation on production rises by $27 \% 9$-relative to the baseline-to finance the $25 \%$ increase in the PIE-to-GDP ratio. The higher taxes impose an additional burden on firms in the economy, reducing their capacity to pay wages and to generate capital returns ( -1.0 and $-0.1 \%$ respectively) to factor owners. Indeed, lower factor returns cause disposable income and consumption to fall marginally $(-0.1 \%)$ among constrained households; while the consumption of non-constrained households rises by $0.6 \%$ in anticipation of increased future income.

The public capital stock increases substantially relative to the baseline scenario in both the short-run (13.3\% in 5 years) and the long-run (26.6\% in 20 years). The accumulation of public capital enhances the marginal productivity of private factor inputs_-labour and private capital_over time, leading to increased real wages and higher capital income. As a result, disposable income of constrained households starts to rise over time to reach a slightly higher level than that recorded in the baseline scenario. It is worth noting that higher wages allow the government to collect more income taxes from households. Hence, the initially considerable rise in the production tax rate needed to finance the $25 \%$ increase in the PIE-to-GDP ratio is dampened in the short and the long-run as higher income taxes help finance the

\footnotetext{
${ }^{9}$ Note: this figure represents the uniform percentage change in the effective production tax rates, and are not necessarily identical across industries. It is also worth mentioning that this increase is not as large as it may seem given that initial production tax ranges from $0.7 \%$ in paper and wood to $9 \%$ in petrochemical sector. The largest new production tax rate is, for example, $11.4 \%$.
} 


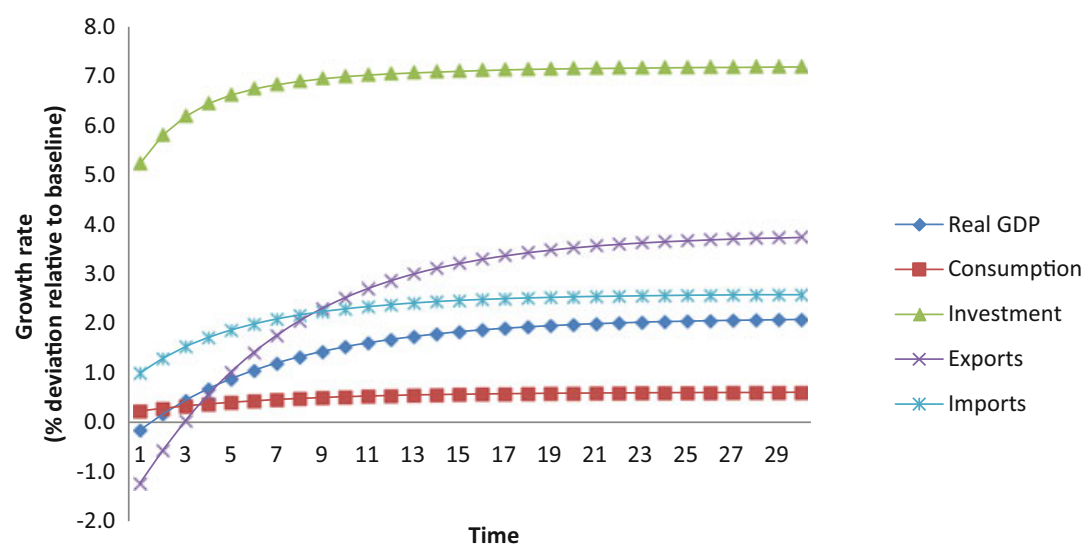

Fig. 8 GDP: demand-side effects (production tax financing) (Source: Authors' computation based on simulation results)

increase in public expenditures. Likewise, higher marginal productivity of private inputs mitigates the increase in the price of investment goods in the long-run, effectively incentivizing private sector investment.

Higher public investment bolsters the total stock of capital in the economy, and provides an impetus to private investment in both the short-run (6.6\%) and the long-run $(7.1 \%)$. This phenomenon of rising public and private investment over time appears to suggest that public infrastructure investments complement private sector investments, i.e., that a crowding-in effect takes place in both the short-run and the long-run. Since profitability is higher under improved productivity, both constrained and non-constrained firms undertake more private investment in the long-run. Non-constrained firms increase their level of investment by more than constrained firms because they anticipate future changes in capital productivity, whereas constrained firms increase their investment to a lesser extent due to the constrained expectations of their owners (constrained households).

Higher productivity helps reduce the burden of higher production taxes and supports improved competitiveness of domestic firms in the international market. This stimulates exports growth, which eventually outpaces import growth in the long-run. The real exchange rate appreciation observed in the first year tapers off in the short and the long-run. Moreover, the higher export growth helps improve the balance of trade. Total short- and long-run consumption respectively grow by 0.4 and $0.6 \%$, as consumption of both constrained and non-constrained households rises in line with increased income.

The net effect of these changes is a relative increase in real GDP of $0.9 \%$ in the short run and $2 \%$ in the long-run. This confirms that additional public infrastructure investments positively affect the economy of the Philippines through productivity and capital accumulation effects that begin to take hold in the short-run (Fig. 8). 


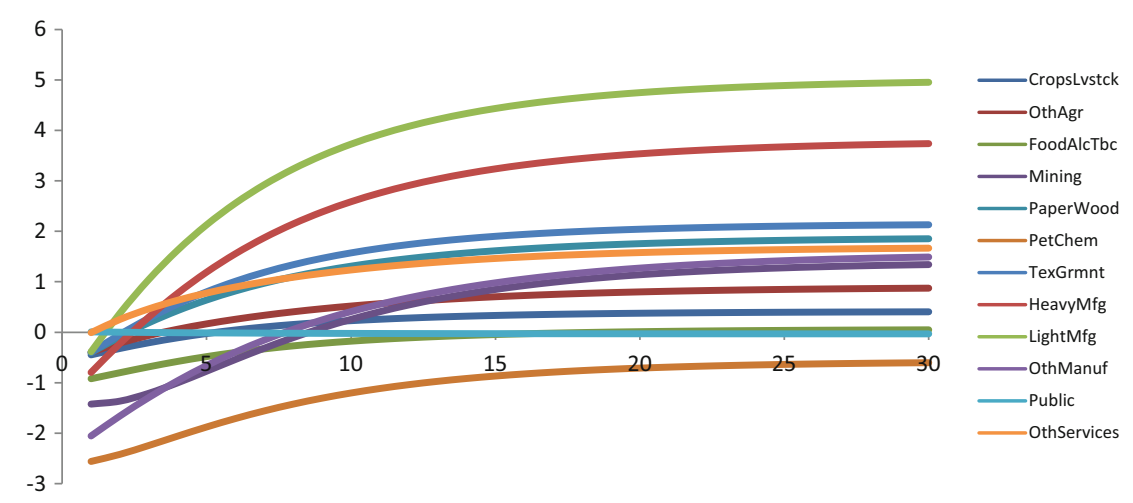

Fig. 9 Effects on sectoral output (production tax financing) (Source: Authors' computation based on simulation results)

Sectoral effects: In contrast to scenario 1, the direct consequence of using a higher production tax to finance public investments in capital infrastructure is a higher cost structure among firms, causing an immediate contraction in output in every producing sector of the economy (See Table 6). In the first period, exports fall significantly in each sector of the economy except in the public services sector as domestic firms lose their competitiveness in the international market. Moreover, the higher domestic cost structure together with increased demand for investment goods leads to a fairly substantial increase in imports, particularly in the light manufacturing $(1.4 \%)$, heavy manufacturing $(1.7 \%)$ and other services $(1.9 \%)$ sectors. Likewise, the food/beverage/tobacco sector registers a $1.8 \%$ rise in imports as the domestic economy substitutes domestically produced goods for cheaper imported products.

In the first year, total domestic demand falls in most sectors, with the exceptions of the light manufacturing, heavy manufacturing and other services sectors, which are more heavily used in public investment. Domestic demand improves in all sectors in the short and the long-run, and this is particularly the case in the light manufacturing, heavy manufacturing and other services sectors (See Fig. 9). In the long run, the positive supply-side effects of higher public investment (capital accumulation and improved productivity) benefit all producers in the economy. This is particularly true for the light and heavy manufacturing, textiles and other services sectors, which register significant output growth in the long-run. Although relatively modest, many other sectors experience the same output expansion effect (crops and livestock, other agriculture, food/alcohol/tobacco). However, output in the food processing and petrochemical sectors remains below its baseline value in the long-run due to increased imports. 


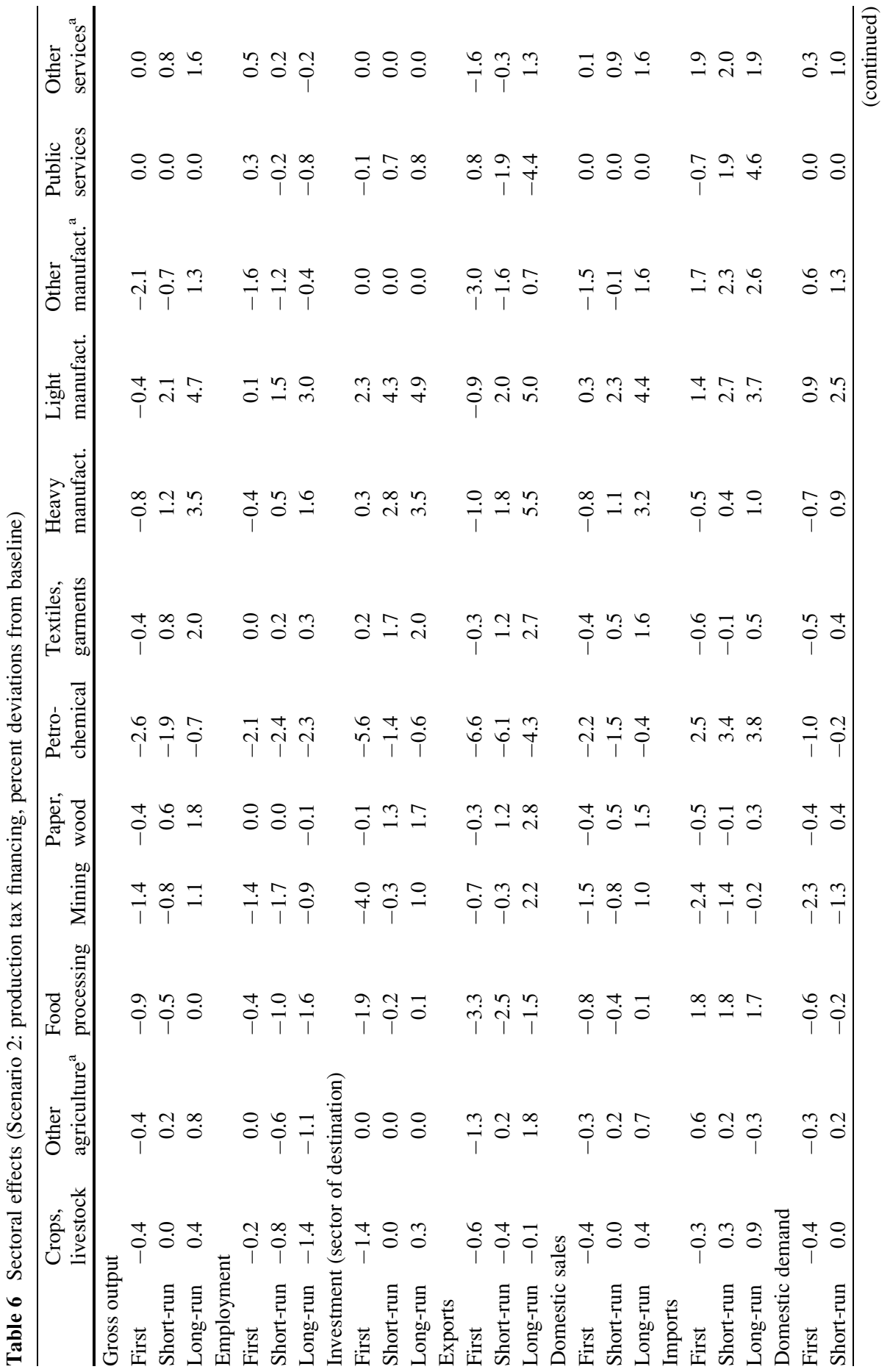




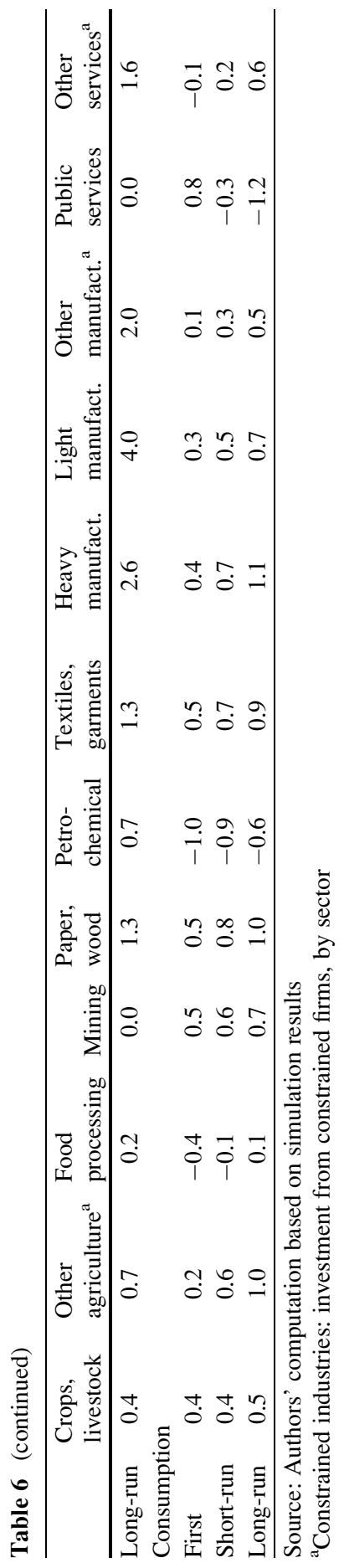




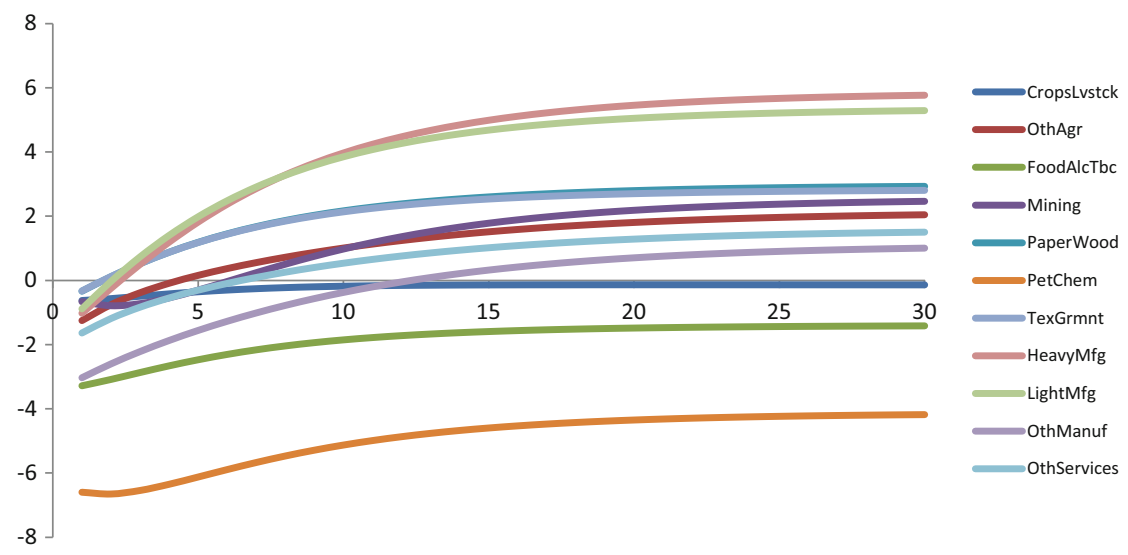

Fig. 10 Effects on exports, by sector (production tax financing) (Source: Authors' computation based on simulation results)

The positive spillover effects of a higher public capital stock improve the competitiveness of domestic producers in the international market. Indeed, exports recover in both the short and the long-run in nearly every sector (See Fig. 10), eventually outpacing relative growth in sectoral imports (See Fig. 11). Food processing and petrochemicals sectors are exceptions in this regard because the Philippines is a net importer of food and oil. Export growth is concentrated in manufacturing sectors (particularly textiles, light manufacturing and heavy manufacturing) which were already export-oriented. Import growth outpaces export growth in the crops/livestock and food/beverage/tobacco sectors throughout the scenario, reflecting the Philippine economy's general dependence on imports in these sectors.

All sectors experience an increase in investment over time (Table 6). As a major producer of capital goods, heavy manufacturing registers the greatest expansion in investment (2.3\% in the first period and $4.9 \%$ in the long-run). This strong investment growth also explains the significant short- and long-run output and export growth in the heavy manufacturing sector, since it directly benefits from the positive supply-side effects of higher public investment. The shadow price of capital immediately rises, and continues to do so in the short run because the increase in public investment crowds out private investment. This price eventually falls in the long-run due to the productivity-enhancing effects of increased public spending on infrastructure.

In summary, the sectoral effects suggest that the productivity-enhancing effects of higher public investment strengthen over time, with the manufacturing and services sectors benefiting relatively more than the agricultural sector in terms of greater output and exports (See Figs. 9 and 10). Compared to scenario 1, the net impact of the tax financing scenario is a reallocation of factors, particularly of labour, from the agricultural sector towards the light manufacturing and heavy manufacturing sectors. 


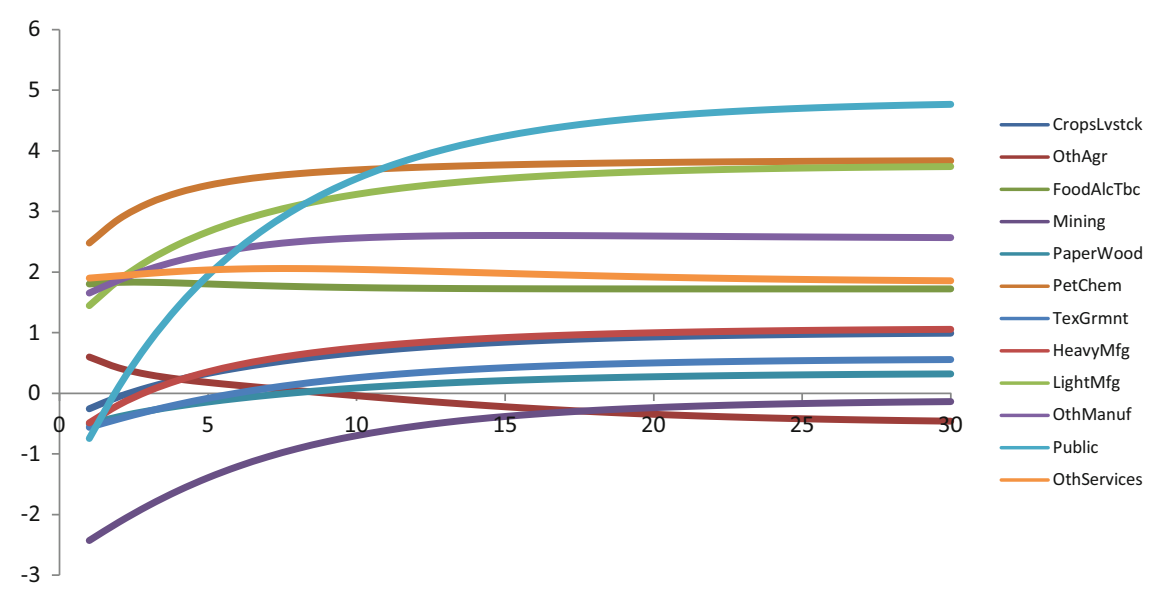

Fig. 11 Effect on imports, by sector (production tax financing) (Source: Authors' computation based on simulation results)

\section{Poverty and Inequality Effects}

We now analyze the poverty and distributional effects of higher public investments in the Philippines. As shown in Table 7, the direction of changes in the poverty headcount and Gini inequality coefficient are identical in both financing scenarios, although the magnitude of the impact is greater under the international financing scenario. The poverty headcounts under the foreign and tax financing scenarios respectively rise by 0.74 and 0.62 percentage points in the first year, but fall in the short and long run (respectively -0.63 and -1.64 under foreign financing and -0.21 and -1.07 under tax financing).

These changes in poverty and inequality result from changes in household income and consumer prices. Indeed, a decomposition of the factors behind changes in the poverty headcount into income and price components (Table 7) reveals that, during the first year and under the tax financing scenario, higher consumer prices and lower income (wages and self-employment) both lead to a higher incidence of poverty. In the foreign financing scenario, however, higher wages limit poverty increase in the first year, but not by enough to offset the impact of higher consumer prices, resulting in a higher incidence of poverty.

The poverty headcount falls in both the short and long run. This occurs because the positive supply-side effects of increased public investment accrue over time, leading to higher wages and returns to capital (Fig. 12). Higher factor returns in the short and long run enhance the poverty-reducing effect of income, offsetting the poverty-increasing effect of higher consumer prices. Regardless of the scenario, it is the combined contribution of wage and self-employment income that allows the 
Table 7 Poverty and inequality effects (percentage points from baseline)

\begin{tabular}{|c|c|c|c|c|c|c|}
\hline & \multicolumn{3}{|c|}{$\underline{\text { International financing }}$} & \multicolumn{3}{|c|}{ Tax financing } \\
\hline & $\begin{array}{l}\text { First } \\
\text { period }\end{array}$ & $\begin{array}{l}\text { Short } \\
\text { run }\end{array}$ & $\begin{array}{l}\text { Long } \\
\text { run }\end{array}$ & $\begin{array}{l}\text { First } \\
\text { period }\end{array}$ & $\begin{array}{l}\text { Short } \\
\text { run }\end{array}$ & $\begin{array}{l}\text { Long } \\
\text { run }\end{array}$ \\
\hline \multicolumn{7}{|l|}{ Poverty headcount } \\
\hline Base (national) & 29.0 & & & & & \\
\hline Simulation & $0.74^{\mathrm{a}}$ & $-0.63^{\mathrm{a}}$ & $-1.64^{\mathrm{a}}$ & $0.62^{\mathrm{a}}$ & $-0.21^{\mathrm{a}}$ & $-1.07^{\mathrm{a}}$ \\
\hline \multicolumn{7}{|c|}{ Components of changes in poverty headcount ${ }^{\mathrm{b}}$} \\
\hline Growth & 0.65 & -0.63 & -1.73 & 0.63 & -0.24 & -1.08 \\
\hline Redistribution & 0.09 & 0.00 & 0.08 & -0.01 & 0.03 & 0.02 \\
\hline \multicolumn{7}{|c|}{ Change (in $\%$ points) in poverty headcount due to change in: } \\
\hline Wage & -0.18 & -0.72 & -1.22 & 0.20 & -0.25 & -0.83 \\
\hline Self-employment & 0.05 & -0.39 & -0.64 & 0.16 & -0.17 & -0.46 \\
\hline Own-consumption & 0.00 & 0.00 & 0.00 & 0.00 & 0.00 & 0.00 \\
\hline Consumer prices & 0.90 & 0.50 & 0.23 & 0.30 & 0.24 & 0.14 \\
\hline Residual & -0.03 & -0.02 & -0.01 & -0.04 & -0.03 & 0.08 \\
\hline \multicolumn{7}{|c|}{ Poverty headcount (by location) } \\
\hline Urban & 0.38 & -0.61 & -1.43 & 0.36 & -0.23 & -0.95 \\
\hline Rural & 1.09 & -0.65 & -1.86 & 0.87 & -0.20 & -1.17 \\
\hline \multicolumn{7}{|c|}{ Poverty headcount (by household type) } \\
\hline Constrained & 0.77 & -0.55 & -1.42 & 0.55 & -0.24 & -0.83 \\
\hline Non-constrained & 0.73 & -0.64 & -1.68 & 0.63 & -0.21 & -1.10 \\
\hline \multicolumn{7}{|l|}{ Gini coefficient } \\
\hline Base (national) & 0.42 & & & & & \\
\hline $\begin{array}{l}\text { Simulation (change in } \% \\
\text { points) }\end{array}$ & 0.036 & -0.013 & -0.004 & 0.016 & -0.003 & -0.006 \\
\hline
\end{tabular}

Source: Authors' calculation based on simulation results

Note: Base poverty headcounts are 14.2 (urban), 43.4 (rural), 45.4 (constrained) and 26.7 (non-constrained)

${ }^{\mathrm{a}}$ The difference (relative to the base year) is statistically different at the $1 \%$ level

${ }^{\mathrm{b}}$ Decomposition based on Shapley value (see Araar and Duclos 2009 for details on using dfgtgr command in DASP)

poverty headcount to fall in the medium and long run, although rising wage income is the dominant factor in this regard.

Table 7 also shows the changes in the poverty headcount by location (urban and rural) and household type (constrained and non-constrained). Households in rural areas are more sensitive to the productivity-enhancing effects of public investment, as reflected by higher short- and long-term reductions in poverty headcounts than their urban counterparts. Similarly, higher returns to factor income drive stronger declines in the poverty headcount among non-constrained households than among constrained households, especially in the long run. 




Fig. 12 Contribution to changes in poverty headcount (scenarios 1 and 2, percentage points from baseline) (Source: Authors' calculation based on simulation results)

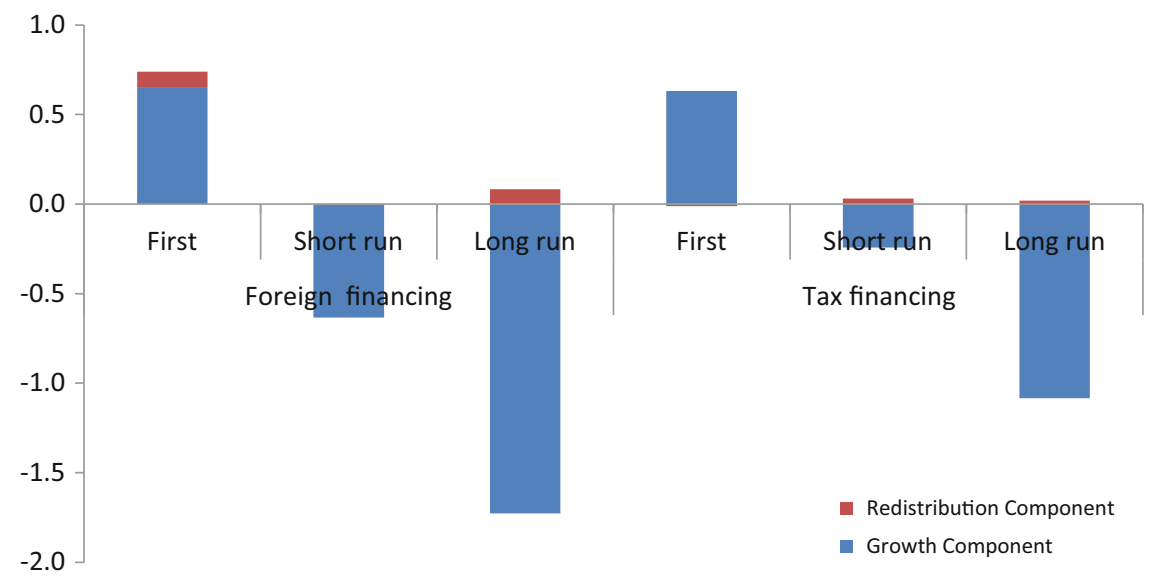

Fig. 13 Growth and redistribution components (changes in poverty headcount, percentage points) (Source: Authors' calculation based on simulation results)

Finally, a decomposition of the factors behind changes in poverty headcounts, into growth and redistribution components (Fig. 13), reveals that, in the long run, the growth component reduces poverty in both the international financing and the tax financing scenarios. 


\section{Sensitivity Analyses}

In addition to the two policy scenarios analyzed above, we also used the model to simulate alternative assumptions regarding the value of the elasticity of output to public capital. We test the sensitivity of the results to our assumed value for the elasticity of output to public capital $(0.15)$ by recalculating our findings with elasticities of 0.1 and 0.2 .

We present these alternative results in Table 8 for selected macroeconomic indicators, the poverty headcount and the Gini coefficient. For the sake of comparison, we present these selected statistics under the original assumption that the elasticity of output to public capital is 0.15 . The general trend observed here is that the magnitude of the results increases with the elasticity of output to public capital. We find that real GDP is at least 0.01 percentage points higher in the first year and is no less than 1 percentage point higher in the long run; the long term impact rises with the elasticity of output to public capital.

The results follow the same general trend in terms of changes in poverty and inequality, both in the first year and in the long run. Indeed, the change in the poverty incidence increases as the elasticity of output to public capital increases from 0.1 to 0.2 . Note that the long-run impact on inequality is slightly lower when testing values of 0.15 and 0.2 for the elasticity of output to public capital. The sensitivity analyses does, however, confirm that the effects of higher public investment on the economy and on poverty in the Philippines are quantitatively robust to differing assumptions in relation to the elasticity of output to public capital.

\section{Summary and Insights}

In the Philippines, public expenditures on physical infrastructure (particularly transportation and utility infrastructures) and the level of public educational spending are both comparatively low. The current government has embarked on policies that aim to further promote robust economic growth and eradicate poverty, in line with commitments to meet its MDGs. One of the policies being pushed primarily concerns infrastructure. This paper contributes to the policy debate on the role of public infrastructure in economic growth and poverty reduction in the Philippines. Our preliminary results reveal that the positive supply-side effects of higher public investment expenditure manifest over time through higher capital accumulation and related improvements in productivity.

In conclusion, the simulation results suggest that a higher public infrastructure investment-to-GDP ratio not only brings about positive real GDP effects, but also reduces poverty and inequality in the short and the long-run. The simulation results follow a generally similar pattern, although the magnitude of the results is greater under the international financing scenario; this is due to the absence of higher 


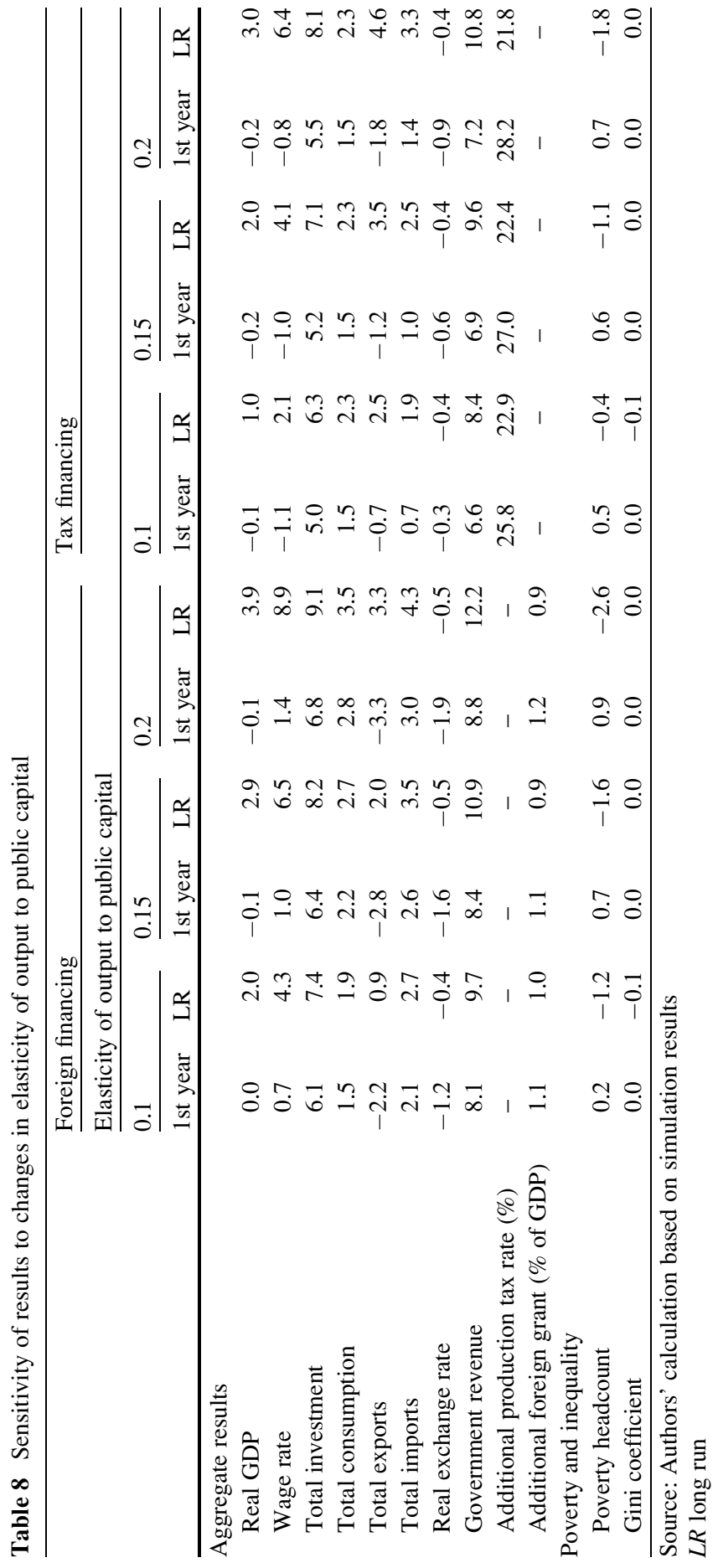


production taxes that slightly hinder the competitiveness of domestic producers. For instance, public infrastructure spending financed by international borrowing at concessional rates of $6 \%$ caused output to expand in all sectors in the long-run, whereas output does not expand in all sectors in the production tax financing scenario. Moreover, the decline in poverty is greater in both the short and long run when increased public infrastructure spending is financed through international borrowing rather than by production taxes. In other words, the selection of a financing scheme for public infrastructure investment matters. The narrow tax base in the country is an important factor that allows our simulation results to confirm that international borrowing is a better alternative to tax financing-i.e., in line with the goal of improving the economy's physical infrastructure to create job opportunities, improve productivity and complement its social protection measures.

Against this backdrop, the Philippine government needs to become more proactive in finding ways to finance increased public investment expenditures. One important policy response is to fast track public-private partnerships (PPPs), to provide financial and technical assistance for infrastructure projects and to increase public education spending. Another is for the government to source additional international financing at concessional rates, or to devise measures to broaden the tax base to finance public investments.

Providing financing for PPP projects in the Philippines is indeed an important issue. The legal and regulatory environment as well as the institutional framework for PPPs has already been established in the country since the 1990s, with PPPs offering nine contractual arrangements-including build-operate-transfer (BOT), build-own-operate (BOO) and build-lease-transfer (BLT) projects, among others. As of August 2012, there were 22 PPPs in the Philippines, including a school infrastructure project (the PSIP); this project aims to build 9,300 public school classrooms for the Philippine government's Department of Education through a BLT at a total cost of US\$239 million. The Philippines has been attracting greater foreign and domestic investments amid improving investor confidence and a liquid financial system. In fact, certain financial institutions-particularly banks and insurance companies-have signalled keen interest in providing financial support for the country's PPP programs, including the PSIP.

To encourage greater private sector participation, government guarantees are being provided to cover the risks inherent to PPP projects. However, if not properly priced and managed, these guarantees create contingent liabilities that could potentially worsen the government's fiscal risks. The Philippine government thus needs to adopt a better framework for granting guarantees: it should include a more accurate pricing mechanism-such as a guarantee fee that fully takes into account the different risks of the project and market conditions - in order to ensure a more efficient allocation of government resources (Llanto 2007). A potential area for future research is to simulate the macroeconomic, sectoral, poverty and income distribution impacts of public infrastructure spending in each key infrastructure sector in the Philippines: education, power, telecommunications, transportation and water. Such an initiative would help policymakers in the country as well as donor 
agencies better allocate their resources to fund the development of each infrastructure sector, thereby promoting inclusive growth and alleviating poverty and income inequality.

Acknowledgements PEP is financed by the Department for International Development (DFID) of the United Kingdom (or UK Aid) and the Government of Canada through the International Development Research Center (IDRC). This particular program of research received separate funding from the Australian Agency for International Development (AusAID). We thank participants in several PEP general meetings, the 2013 GTAP annual conference in Beijing and the 2013 GDN annual conference in Manila for helpful comments. We also salute the support and advice provided by governmental and non-governmental counterparts. In particular, the authors are grateful to John Cockburn, Yazid Dissou, Jean-Yves Duclos and Luca Tiberti for technical support and guidance, as well as Tomas Africa and Randy Spence for valuable comments and suggestions.

Open Access This chapter is distributed under the terms of the Creative Commons Attribution Noncommercial License, which permits any noncommercial use, distribution, and reproduction in any medium, provided the original author(s) and source are credited.

\section{Appendix 1: Figures}

Fig. 14 Power generation/ consumption in the Philippines, 1991-2010 (gigawatt-hours) (Source of basic data: Department of Energy, Republic of the Philippines)

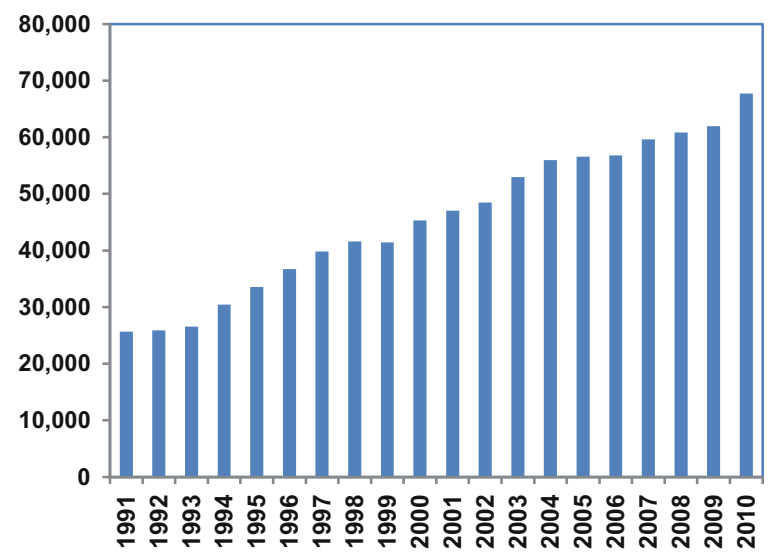


Fig. 15 Proportion of population with access to improved water source in the Philippines: 1990, 1995, 2000, 2005, 2008 (Source of basic data: The World Bank's World Development Indicators Database)

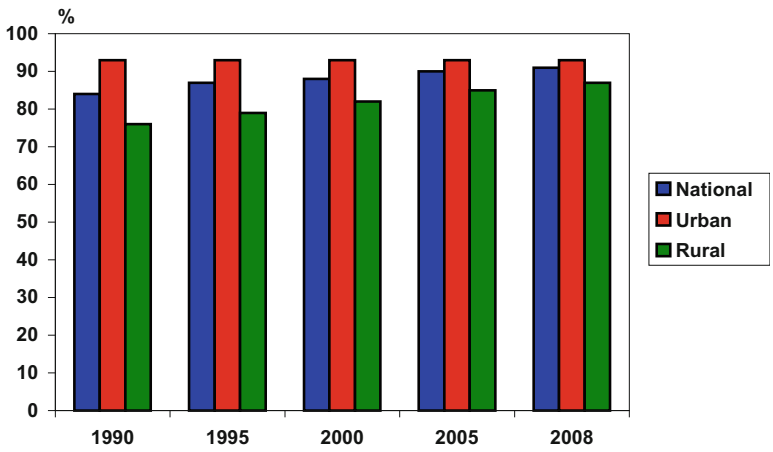

\section{Appendix 2: Tables}

Table 9 Poverty incidence for selected subpopulation characteristics based on 2006 Philippine FIES

\begin{tabular}{|c|c|c|c|c|c|}
\hline Variable & Estimate & $\begin{array}{l}\text { Standard } \\
\text { Error }\end{array}$ & Variable & Estimate & $\begin{array}{l}\text { Standard } \\
\text { Error }\end{array}$ \\
\hline \multicolumn{3}{|c|}{ Type of household } & \multicolumn{3}{|c|}{ Class of worker (household head) } \\
\hline $\begin{array}{l}\text { Single } \\
\quad \text { household }\end{array}$ & 0.277 & 0.003 & $\begin{array}{c}\text { Worked for private } \\
\text { Establishment }\end{array}$ & 0.257 & 0.004 \\
\hline \multirow{3}{*}{$\begin{array}{l}\text { Extended } \\
\quad \text { household }\end{array}$} & 0.249 & 0.004 & Work for the government & 0.194 & 0.008 \\
\hline & & & $\begin{array}{l}\text { Self-employed without } \\
\text { any employee }\end{array}$ & 0.347 & 0.004 \\
\hline & & & $\begin{array}{l}\text { Employer in own family- } \\
\text { operated }\end{array}$ & 0.237 & 0.008 \\
\hline Headship & & & $\begin{array}{l}\text { Worked with pay in own } \\
\text { family-op }\end{array}$ & 0.173 & 0.051 \\
\hline Male headed & 0.286 & 0.002 & $\begin{array}{l}\text { Worked without pay in } \\
\text { own family }\end{array}$ & 0.165 & 0.026 \\
\hline Female headed & 0.202 & 0.005 & & & \\
\hline \multicolumn{3}{|c|}{ Marital status of household head } & \multicolumn{3}{|c|}{ Number of members Employed } \\
\hline Single & 0.171 & 0.010 & 1 & 0.284 & 0.004 \\
\hline Married & 0.283 & 0.003 & 2 & 0.267 & 0.004 \\
\hline Widowed & 0.233 & 0.006 & 3 & 0.259 & 0.007 \\
\hline $\begin{array}{l}\text { Divorced/ } \\
\text { separated }\end{array}$ & 0.199 & 0.014 & 4 & 0.273 & 0.011 \\
\hline Unknown & 0.463 & 0.250 & 5 & 0.297 & 0.020 \\
\hline \multicolumn{3}{|c|}{ Job status of the household head } & 6 & 0.306 & 0.041 \\
\hline $\begin{array}{l}\text { with } \\
\text { job/business }\end{array}$ & 0.182 & 0.005 & 7 & 0.273 & 0.77 \\
\hline no job/business & 0.287 & 0.002 & 8 & 0.161 & 0.107 \\
\hline
\end{tabular}

Source: Authors' computations using FIES 


\section{Bibliography}

Araar A, Duclos J-Y (2009) User manual for Distributive Analysis STATA package (DASP). Universite Laval, Quebec

Aschauer D (1989) Is public expenditure productive? J Monetary Econ 23(2):177-200

Albert JR, Collado P (2004) Profile and determinants of poverty in the Philippines. 9th National Convention on Statistics, Mandaluyong City

Arslanalp S, Bornhorst F, Gupta S (2011) Investing in growth. Financ Dev 48(1):34-37

Calderon C, Chong A (2004) Volume and quality of infrastructure and the distribution of income: an empirical investigation. Rev Income Wealth 50(1):87-106

Cockburn J, Duclos J-Y, Tiberti L (2011) Notes on microsimulation model and results for Benin, mimeo, Department of Economics, Université Laval, Quebec

Cororaton C, Corong E (2009) Philippine agricultural and food policies: implications for poverty and income distribution. International Food Policy Research Institute (IFPRI) research report no. 161. IFPRI, Washington, DC

Dissou Y, Didic S (2011) Public infrastructure and economic growth: a dynamic general equilibrium analysis with heterogeneous agents, mimeo, Department of Economics, University of Ottawa, Ottawa

DOE (2010) Philippine power situationer. Department of Energy, Fort Bonifacio Global City, Taguig

Duclos J-Y, Araar A (2006) Poverty and equity: measurement, policy, and estimation with DAD. Springer, New York

Foster JE, Greer J, Thorbecke E (1984) A class of decomposable poverty indices. Econometrica 52:761-766

Gupta S, Kangur A, Papageorgiou C, Wane A (2011) Efficiency-adjusted public capital and growth, IMF working paper 11/217. International Monetary Fund, Washington, DC

Ibazeta J (2010) The power outlook. Presentation to the Philippine Economic Society, NEDA sa Makati Building, Makati City, 29 June 2010

Isaksson A (2009) Public capital, infrastructure and industrial development. UNIDO Working Paper 15. United Nations Industrial Development Organization, Vienna

Llanto G (2007) Dealing with contingent liabilities: The Philippines. In: Ito T, Rose A (eds) Fiscal policy and management in East Asia. The University of Chicago Press, Chicago

Paderanga C (2010) The Philippine economy: performance, prospects, challenges, and strategies. Presentation at the House of Representatives, Quezon City, 01-02 Sept 2010

Savard L (2010) Scaling up infrastructure spending in the Philippines: a CGE top-down bottom-up microsimulation approach. Int J Microsimulat 3(1):43-59

Teruel R, Kuroda Y (2005) Public infrastructure and productivity growth in Philippine agriculture, 1974-2000. J Asian Econ 16(3):555-576

World Development Indicators (2009) The world development indicators database. The World Bank, Washington, DC

World Economic Forum (2010) The global competitiveness report 2010-2011. World Economic Forum, Geneva

Zhai F (2010) The benefits of regional infrastructure investment in Asia: a quantitative exploration. ADBI working paper 223. Asian Development Bank Institute, Tokyo 